\title{
Selective Modification of Sulfamidate-Containing Peptides
}

Received 00th January 20xx, Accepted 00th January 20xx DOI: $10.1039 / \times 0 \times x 00000 x$

\author{
Nuria Mazo, ${ }^{a}$ Claudio D. Navo, ${ }^{b}$ Jesús M. Peregrina, ${ }^{a}$ Jesús H. Busto, ${ }^{a}$ and Gonzalo Jiménez-Osés*b
}

Hybrid peptides whose $N$-terminal residues are activated in the form of $\alpha$-methylisoserine-derived cyclic sulfamidates exhibit a rich reactivity as electrophiles, allowing site- and stereoselective modifications at different backbone and sidechain positions. The unique properties of this scaffold allow the stereocontrolled late-stage functionalization of the peptide backbone by nucleophilic ring opening with fluorescent probes, thiocarbohydrates and tags for strain-promoted azidealkyne cycloaddition, as well as installing labile $\mathrm{N}$-terminal affinity tags (biotin) and cytotoxic drugs (chlorambucil) for $\mathrm{pH}$ controlled release. Finally, an unexpected base-promoted acyl group migration from the sulfamidate $\mathrm{N}$-terminus allows fast and quantitative intramolecular modification of nucleophilic sidechains on the fully unprotected peptides.

\section{Introduction}

The site-selective modification of peptides with enriched biological functions, particularly in near-physiologic conditions, entails a significant challenge for chemical biology due to the similar reactivity of their amino acid constituents. ${ }^{1-3}$ Considerable progress has been made in this field by using tagged $^{4-6}$ or customizable units, ${ }^{7-10}$ although differentiating among similar units within the same or coexisting peptides, commonly poses an additional problem. In this context, performing chemical reactions on a solid support has considerable advantages with respect to solution phase chemistry. ${ }^{11-13}$ Reaction mixtures are commonly cleaner, lower purification steps are needed, and, in a peptide context, solidphase synthesis allows the controlled elongation of the peptide chain. ${ }^{14-16}$ Several types of reactions using a solid support have been described in addition to prototypical amide bond formation to obtain labelled peptides, such as copper(I) catalyzed azide-alkyne cycloadditions, ${ }^{17}$ Michael additions, ${ }^{18}$ cysteine S-alkylation, ${ }^{19}$ or ring-opening of aziridines. ${ }^{20,21}$

Cyclic sulfamidates are versatile building blocks and highly customizable units for the regio- and stereoselective synthesis of amino acids, lactams, diazepines and valuable intermediates in drug development through nucleophilic ring-opening reactions. ${ }^{22,23}$ However, to date, only a few cases of heterogeneous reactions using cyclic sulfamidates have been reported. Cohen and Halcomb introduced sulfamidates derived from natural $\beta$-hydroxyamino acids, L-serine and L-threonine, in immobilized peptides and carried out ring-opening reactions on

\footnotetext{
a. Departamento de Química, Universidad de La Rioja, Centro de Investigación en Sintesis Química, E-26006 Logroño, Spain

b. Center for Cooperative Research in Biosciences (CIC bioGUNE), Basque Research and Technology Alliance (BRTA), Bizkaia Technology Park, Building 801A, 48160 Derio, Spain

Electronic Supplementary Information (ESI) available: experimental characterization of new compounds, HPLC chromatograms and NMR data. See DOI: $10.1039 / x 0 x x 00000 x$
}

resin using $\beta$-1-thioglucose as a nucleophile to obtain thioglycopeptides. ${ }^{24}$ Additionally, Lubell performed sulfamidate ring-opening reactions using a peptide bound to the resin to obtain $\beta$ - and $\gamma$-lactams. ${ }^{25-27}$ We have recently reported the ringopening of cyclic sulfamidates derived from $\alpha$-methylisoserine with $S$ - and $N$-nucleophiles in a peptide context in homogenous phase. ${ }^{28,29}$ These reactions proceeded at the sulfamidate tetrasubstituted carbon atom with complete inversion of the configuration at this stereocenter, giving rise to hybrid peptides. However, this methodology was limited to di- or tri-peptides. Herein, we report a methodology for on-resin site- and stereoselective chemical modification of longer peptides through the ring-opening of immobilized cyclic sulfamidates derived from $\alpha$-methylisoserine, and further labeling of the resulting linear peptides. Additionally, the special reactivity of the $\mathrm{N}$-terminus of sulfamidate-modified peptides is explored for potential $\mathrm{pH}$-controlled drug release and selective side-chain modification via intramolecular $\mathrm{N} \rightarrow \mathrm{X}$ acyl shift.

\section{Results and discussion}

\section{Selective peptide backbone modification}

Following the strategy developed in our group for coupling cyclic sulfamidate $\mathbf{1}$ derived from $\alpha$-methylisoserine to natural peptides in solid phase, ${ }^{\ddagger}$ peptide 2 (1-Ala-Pro-Asp-Thr-Arg-Pro) was synthesized using solid-phase peptide synthesis (SPPS) with microwave activation. The sequence Ala-Pro-Asp-Thr-Arg-Pro is a well-known epitope of the MUC-1 mucin, which has been closely related to several types of cancer ${ }^{30,31}$ and used for the development of anticancer vaccines. ${ }^{32-35}$ Alternatively, acetylation at the $\mathrm{N}$-terminus of the sulfamidate before resin cleavage using a 1:2 mixture of acetic anhydride $\left(\mathrm{Ac}_{2} \mathrm{O}\right)$ and pyridine afforded peptide 3 (Ac-1-Ala-Pro-Asp-Thr-Arg-Pro) in a $78 \%$ global yield after HPLC purification (Scheme 1 ). As recently reported, capping of the $\mathrm{N}$-terminus of the sulfamidate is necessary to enable nucleophilic ring-opening reactions. ${ }^{36}$ 


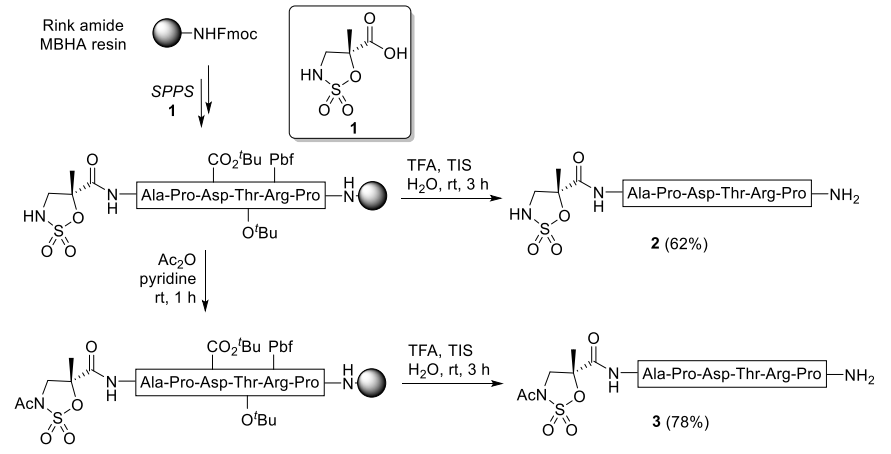

Scheme 1. Solid-phase synthesis of sulfamidate-containing peptides $\mathbf{2}$ and $\mathbf{3}$. TFA = trifluoroacetic acid; TIS = triisopropylsilane; $\mathrm{Pbf}=$ 2,2,4,6,7-pentamethyldihydrobenzofuran-5-sulfonyl; yields refer to HPLC-purified compounds.

The azide functionality is widely used for bioorthogonal and bioconjugation applications given its superior reactivity in traceless reactions with phosphines (Staudinger ligation) and alkynes. ${ }^{37,38} \mathrm{~A}$ widely used strategy for labelling peptides and proteins is the so-called strain-promoted alkyne-azide cycloaddition (SPAAC). ${ }^{39,40}$ Thus, we assayed the potential of sulfamidate-containing peptides as transient electrophiles for the site-selective installation of the azide group and subsequent trapping with strained cycloalkynes. As a control reaction in solution, peptide 3 was dissolved in $\mathrm{H}_{2} \mathrm{O}$ and reacted with 20 equiv. of sodium azide at room temperature. The reaction was monitored by HPLC (ESI fig. S1) observing a fast consumption of the starting material and the appearance of two new peaks after $2 \mathrm{~h}$. Azide-labelled peptide 4' was obtained as the main product $(31 \%)$, while the minor peak (15\%) corresponded to $\mathrm{N}$ deacetylated peptide $\mathbf{2}$ (Scheme 2). Since the reaction mixture was not subjected to the typical acidic workup after sulfamidate ring-opening, the sulfamic acid moiety $\left(\mathrm{SO}_{3}{ }^{-}\right)$remained attached at the $\mathrm{N}$-terminus of the peptide. Reducing the amount of azide did not avoid the nucleophilic cleavage of the sulfamidate $\mathrm{N}$-acetyl group and was detrimental for ringopening ( $18 \%$ and $35 \%$ yields of 4' and 2, respectively, after 18 h using 2 equiv. of sodium azide). Such undesired partial deprotection has been recursively observed in our group in similar reactions in solution. ${ }^{28,41}$

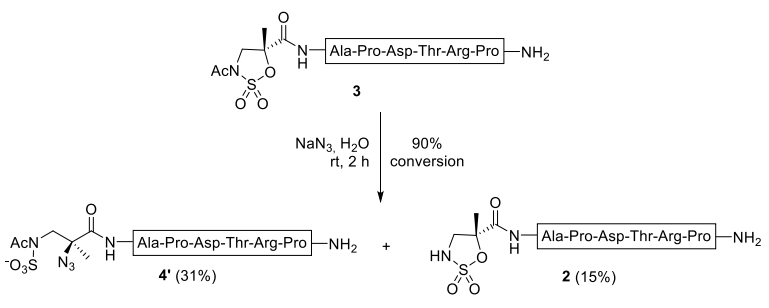

Scheme 2. Ring-opening reaction of peptide $\mathbf{3}$ with sodium azide in water solution. Conversion was estimated from the integration of HPLC signals in the reaction mixture (Fig. S1); yields refer to HPLC-purified compounds.

However, a substantial improvement was observed when the same ring-opening reaction was performed in the solid phase. After reacting the immobilized version of peptide 3 with 20 equiv. of sodium azide (relative to the used resin) for $3 \mathrm{~h}$ at room temperature in DMF, and subsequent removal of protecting groups including the $\mathrm{N}$-terminal sulfamic acid, resin cleavage and purification by HPLC, the desired azide-labelled peptide 4 was obtained in a $31 \%$ global yield (Scheme 3 ). Of note, $N$-deacetylation was completely supressed under these conditions (ESI fig. S2). Peptide 4 was obtained with high diastereomeric purity ( $>95 \%$ as determined by HPLC and NMR), demonstrating that a $\mathrm{S}_{\mathrm{N}}$ 2-type mechanism, demonstrated previously for small-molecule variants, ${ }^{36,42}$ also operates in a solid-phase peptide context.

Peptide 4 was further reacted with 2 equiv. of strained cyclooctyne bicyclo[6.1.0]non-4-yn-9-ylmethanol (BCN-OH), a common handle used in SPAAC bioconjugations, in a 1:3 mixture of $\mathrm{H}_{2} \mathrm{O} /$ acetonitrile at $25{ }^{\circ} \mathrm{C}$. The 1,3-dipolar cycloaddition was completed in $2 \mathrm{~h}$ ( $>85 \%$ conversion after 30 $\mathrm{min}$ ) and the expected azide-alkyne conjugate was obtained as a $\mathbf{1 : 1}$ mixture of diastereomers $\mathbf{5 a}$ and $\mathbf{5} \mathbf{b}$ in a $77 \%$ combined yield after HPLC purification (Scheme 3 and ESI fig. S3).

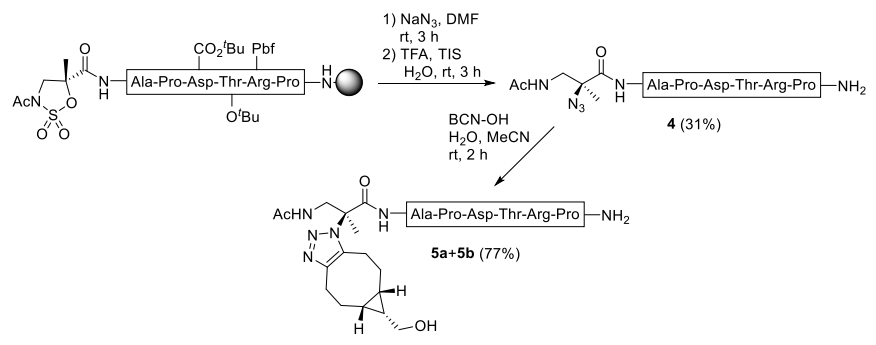

Scheme 3. On-resin ring-opening of peptide $\mathbf{3}$ with sodium azide and subsequent click cycloaddition with $\mathrm{BCN}-\mathrm{OH}$; yields refer to HPLC-purified compounds.

Fluorescent peptides are widely used as imaging agents for direct visualization of biochemical processes in cells. ${ }^{43-45}$ Hence, immobilized peptide 3 was labelled on-resin with fluorescent 7mercapto-4-methylcoumarin 6 (10 equiv.) in the presence of $\mathrm{N}, \mathrm{N}$-diisopropylethylamine (DIPEA) as a base in DMF. After stirring at room temperature for $1.5 \mathrm{~h}$ and subsequent resin cleavage and HPLC purification, conjugated peptide 7 was obtained in a $45 \%$ global yield as a single product (Scheme 4 ). The fluorescent properties of peptide 7 were evaluated, observing an excitation maximum ( $\left.\lambda_{\text {exc }}\right)$ at $331 \mathrm{~nm}$ and an emission maximum ( $\lambda_{\mathrm{em}}$ ) at $399 \mathrm{~nm}$ in DMSO (ESI fig. S4).

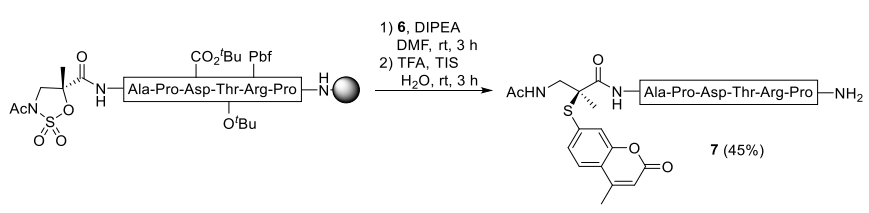

Scheme 4. On-resin ring-opening of peptide $\mathbf{3}$ with coumarin derivative 6.; yields refer to HPLC-purified compounds.

Glycosylation is one of the most prevalent post-translational modifications (PTM) occurring in peptides and proteins, with a defining impact on its structure and function. ${ }^{46}$ Particularly, $S$ glycosylation of cysteine residues is observed in biologically active peptides such as antimicrobial sublancin. ${ }^{47}$ We have previously used thiocarbohydrates as nucleophiles for the ringopening of hindered cyclic sulfamidates as electrophiles to 
synthesize hybrid glycopeptides in solution. ${ }^{28,29}$ Here, the glycosylation of immobilized peptide $\mathbf{3}$ was performed on-resin using tetra- $O$-acetyl- $\beta$-1-thioglucose $\mathbf{8}$ ( 10 equiv.) and DIPEA as a base. After stirring at room temperature for $1.5 \mathrm{~h}$, removal of the carbohydrate $O$-acetyl protecting groups with a solution of 70\% hydrazine in methanol, resin cleavage and HPLC purification, glycoconjugated peptide 9 was obtained in a $16 \%$ global yield (Scheme 5) Again, peptide by-products were not observed. Notably, the acetyl group at the peptide $\mathrm{N}$-terminus was removed during the process likely by the action of hydrazine, which precluded the cleavage of the sulfamic acid normally removed upon acidic treatment.

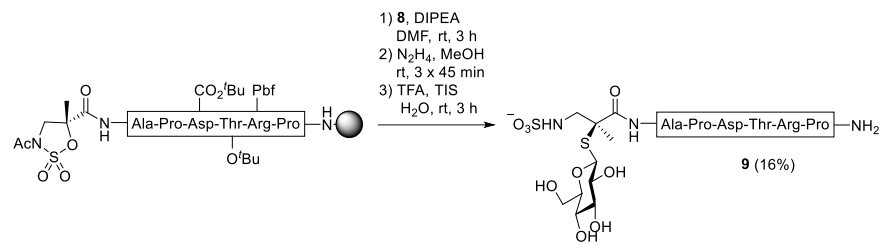

Scheme 5. On-resin ring-opening of peptide $\mathbf{3}$ with thiocarbohydrate $\mathbf{8}$; yields refer to HPLC-purified compounds.

\section{Selective $\mathbf{N}$-terminal modification and $\mathrm{pH}$-controlled release}

Carbonyl functional groups (i.e. amides and carbamates) attached to the $\mathrm{N}$ atom of cyclic sulfamidates derived from amino acids have been observed to be highly reactive towards different types of nucleophiles, particularly in aqueous environments, often leading to undesired deprotection side reactions. ${ }^{24,28,41,48}$ Likewise, the special reactivity of $\mathrm{N}$-acyl- $\mathrm{N}$ alkylsulfonamides has been used to develop 'safety-catch' linkers for the solid-phase synthesis of peptide thioesters. ${ }^{49,50}$ We decided to exploit this special reactivity of $\mathrm{N}$-carbonyl sulfamidates as an effective strategy to regulate the release of chemical functionalities in a controlled manner (i.e. chemical decaging or release)..$^{51-53}$ Therefore, two biologically relevant molecules such as a biotin (Btn-OH), a high-affinity label used in affinity chromatography and proteins/antibodies defection, 54,55 and chlorambucil ( $\mathrm{Clb}-\mathrm{OH})$, a chemotherapeutic drug frequently used for the treatment of some types of cancer, ${ }^{56,57}$ were coupled on-resin to the $N$ - terminus of immobilized peptide 3 using TBTU and DIPEA as coupling agents in DMF at $-20{ }^{\circ} \mathrm{C}$ for $45 \mathrm{~min}$. Resin cleavage and purification by HPLC afforded peptides $\mathbf{1 0}$ and $\mathbf{1 1}$ in 33\% and 62\% yields, respectively (Figure 1a). A kinetic study of $\mathrm{pH}$-dependent chlorambucil release was performed in different media. Hence, peptide $\mathbf{1 0}$ was dissolved in phosphate buffered saline (PBS, $\mathrm{pH}$ 7.4) simulating the physiological medium of a healthy cell environment, and a second sample was dissolved in a slightly acidic solution $(\mathrm{pH}$ 6.3), simulating cancer cells environments. ${ }^{58-61}$ Both samples were separately incubated at $25{ }^{\circ} \mathrm{C}$. Aliquots were taken periodically and monitored by analytical HPLC (ESI fig. S5). An exponential decay was observed for the concentration of peptide 10, corresponding to pseudo-first order kinetics for the hydrolytic decaging reaction (Figure 1). In parallel, signals of increasing intensity corresponding to peptide $\mathbf{2}$ and free chlorambucil were observed. Notably, acidic medium accelerates payload cleavage by nearly 4 -fold as reflected by the measured kinetic rate constants $\left(k_{6.3}=6.4 \cdot 10^{-5} \mathrm{~s}^{-1} ; k_{7.4}=1.7\right.$. $10^{-5} \mathrm{~s}^{-1}$, Figure $\left.1 \mathrm{~b}, \mathrm{c}\right)$. These results suggest that the cytotoxic drug would remain attached to the sulfamidate-containing peptide for longer times in healthy cells, while it would be released slightly faster at the surroundings of more acidic cancer cells. This strategy, thus, poses potential for selective chemotherapy applications although the potential reactivity of the sulfamidate-modified peptides towards biological nucleophiles, particularly thiols (i.e. glutathione) might limit its practical use.
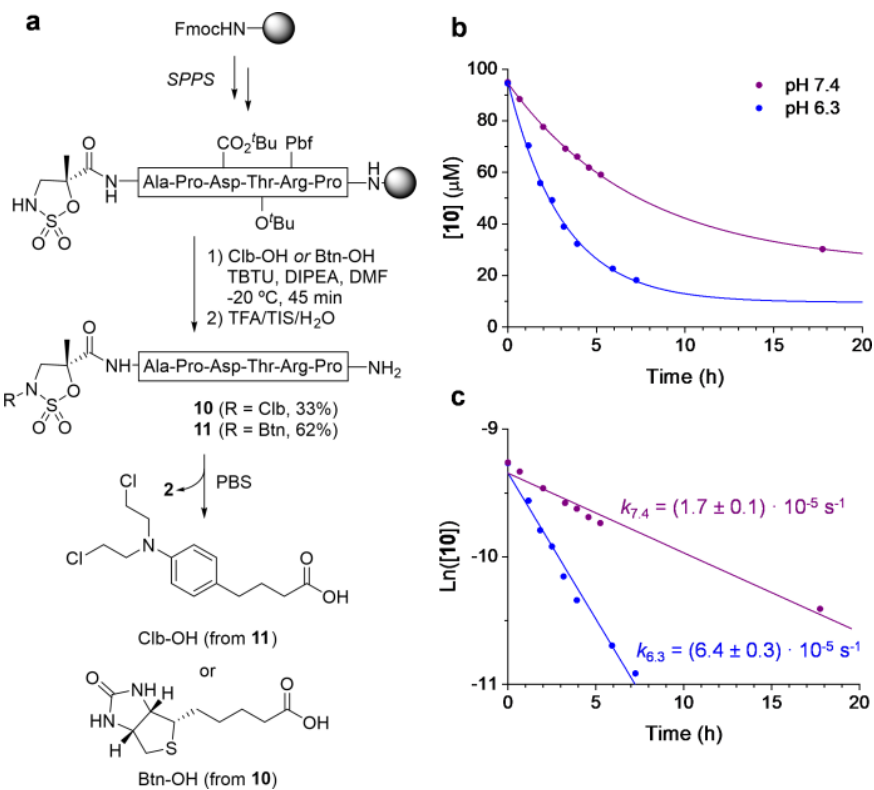

Fig. 1. a) Sold-phase synthesis of peptides 10 and $\mathbf{1 1}$ and subsequent $\mathrm{pH}$ controlled release. b) Evolution of peptide $\mathbf{1 0}$ concentration at $\mathrm{pH} 7.4$ (blue) and 6.3 (purple) at $25^{\circ} \mathrm{C}$. c) Estimation of the pseudo-first order kinetic constants at $\mathrm{pH} 7.4$ (blue) and 6.3 (purple) using the linearly fitted region of the $\operatorname{Ln}[10]$ vs. time plot. The reported apparent hydrolysis pseudo-first order constants (average \pm standard deviation) include the concentration of bulk water (ca. $55 \mathrm{M}$ ). Experimental data shown in panels $\mathbf{b}$ and $\mathbf{c}$ were fitted using exponential $([\mathbf{1 0}]=$ $\left.[10]_{0} \mathrm{e}^{-k t}\right)$ and linear $\left(\operatorname{Ln}[10]=\operatorname{Ln}[10]_{0}-k \mathrm{t}\right)$ equations, respectively, using Microcal OriginPro 2019 software.

\section{Selective side-chain modification via intramolecular $\mathbf{N} \rightarrow \mathbf{X}$ acyl shift}

Certain proteins are able to excise part of their sequence (inteins) and join the remaining segments (exteins) by a process known as intein-mediated protein splicing. ${ }^{62-64}$ In class-II inteinlike peptides, this process is initiated by an intramolecular $\mathrm{N} \rightarrow \mathrm{S}$ acyl shift followed by a trans(thio)esterification reaction. ${ }^{65}$ Inspired by this biological transformation, and once the $\mathrm{pH}$ controlled release of $\mathrm{N}$-carbonyl groups from sulfamidatecontaining peptides was demonstrated, we envisioned their selective side-chain modification by intramolecular $\mathrm{N} \rightarrow \mathrm{X}(\mathrm{X}=\mathrm{S}$, $\mathrm{N}, \mathrm{O})$ transacylation of cleavable moieties to nucleophilic residues embedded in the peptide sequence. Thus, sulfamidatemodified peptides 12-15 bearing a Fmoc-protected alanine at the $\mathrm{N}$-terminus were synthesized in $30-49 \%$ global yields after HPLC purification (Scheme 6). The Ala-His-Asn-Xxx-Gly (Xxx = Cys, Ser, Thr, Lys) sequence was selected since it is a common motif found in class-II intein-like peptides. ${ }^{66}$ The influence of the 
nucleophilic residue location relative to the sulfamidate linkage in the outcome of the acyl group migration, was also examined by synthesizing peptides 16-18 (30-35\% global yields after HPLC purification). Since the peptides resulting from the hypothesized transacylation reactions would have identical molecular weights and very similar HPLC elution properties than those of the starting materials, we selected ${ }^{1} \mathrm{H}$ NMR to monitor reaction progress. First, peptide 12 was dissolved in a 24:1 $\mathrm{CD}_{3} \mathrm{CN} / \mathrm{D}_{2} \mathrm{O}$ mixture and a slight excess of triethylamine (TEA, 1.6 equiv.) was added as a base to activate Cys at room temperature. Complete conversion to a unique new product was observed immediately after increasing the $\mathrm{pH}$ of the solution (ESI fig. S6). Accordingly, HPLC analysis of the mixture showed a unique signal at a retention time very similar to that of the starting peptide, and the HPLC purified peptide 19 showed a mass identical to that of the starting material (ESI fig. S13). These results suggested that the Fmoc-Ala residue had been transferred from the nitrogen atom of the sulfamidate to the sulfur atom of the cysteine via intramolecular $\mathrm{N} \rightarrow \mathrm{S}$ transacylation, instead of the cysteine undergoing sulfamidate ring-opening as commonly observed in small-molecule reactions. This was further confirmed by recovering peptide $\mathbf{1 9}$ completely unreacted after treatment with a large excess of $\mathrm{N}$ ethylmaleimide (NEM), which indicated complete cysteine modification unlike in Cys-unprotected control peptide 26 (ESI fig. S20). The transacylation reaction was demonstrated to be equally efficient irrespective of the relative positions of the reacting cysteine and the sulfamidate residue, and the peptide length, cleanly yielding sidechain-modified peptides 20-22 from activated peptides 16-18 (ESI figs. S10-12 and S17-S19).

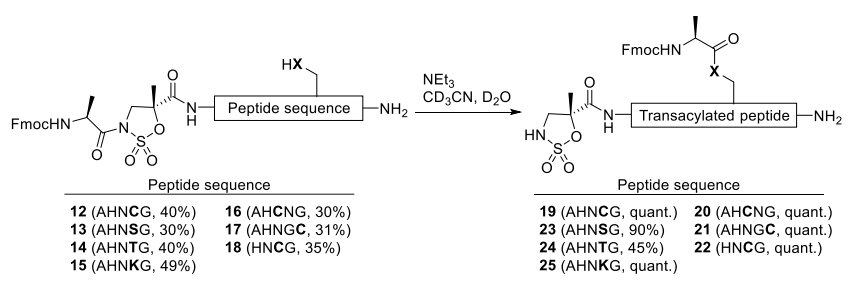

Scheme 6. Chemical structure of intein-like sulfamidate-containing peptides 12-18 and the corresponding transacylated peptides 19-25. Modified residues appear in boldface. Yields (\%) for peptides 12-18 were calculated as mmol of HPLC-purified compound divided by mmol of resin labelling content. Conversion values for peptides 19-25 were derived from the ${ }^{1} \mathrm{H}$ NMR spectra of reaction mixtures.

The acyl migration reaction was not limited only to cysteine and proceeded equally fast with peptide $\mathbf{1 5}$ bearing a nucleophilic lysine to cleanly yield sidechain-modified peptide $25(90 \%$ conversion, ESI figs. S9 and S16). However, peptides $\mathbf{1 3}$ and $\mathbf{1 4}$ bearing much less acidic serine and threonine residues, respectively, the transacylation reaction was not completed after $3 \mathrm{~h}$ (ESI fig. S7-S8 and S14-S15). Of note, the histidine residues present in all assayed peptides remained unreacted in all cases. The discovery of this, to our knowledge, unprecedented $\mathrm{N} \rightarrow \mathrm{X}(\mathrm{X}=\mathrm{S}, \mathrm{N}, \mathrm{O})$ transacylation reaction offers new possibilities for the efficient and selective peptide sidechain modification.

\section{Conclusions}

We have expanded the use of $\alpha$-methylisoserine-derived cyclic sulfamidates for the synthesis and selective chemical modification of hybrid peptides in near-physiological conditions. Solid-phase peptide synthesis allowed the efficient coupling of such sulfamidates to the $\mathrm{N}$-terminus of different peptide sequences, and subsequent site-selective and stereocontrolled installation of a fluorescent label, an azide tag for further bioconjugation and a post-translational modification. The special reactivity of carbonyl groups linked to the sulfamidate $\mathrm{N}$-terminus allowed attaching labile affinity tags and an anticancer drug for controlled release in slightly acidic environments such as those found in cancer cells. Also, we describe for the first time the spontaneous transacylation reaction on nucleophilic sidechains in the peptide sequence. Overall, we demonstrate the value of chiral cyclic sulfamidates as versatile tools for bioconjugation and the selective chemical modification of peptides.

\section{Experimental}

\section{Reagents and general procedures}

Commercial reagents were used without further purification. Solvents were dried and redistilled prior to use. Thin-layer chromatography (TLC) was performed on silica gel plates (Polychrom SI F254), using UV-light, phosphomolybdic acid, potassium permanganate or ninhydrin as stains. Column chromatography was performed using silica gel $(0.04-0.06 \mathrm{~mm}$, 230-240 mesh). ${ }^{1} \mathrm{H}$ and ${ }^{13} \mathrm{C}$ NMR spectra were measured with Bruker Avance-400 and Bruker ARX-300 spectrometers in $\mathrm{D}_{2} \mathrm{O}$ or $\mathrm{H}_{2} \mathrm{O} / \mathrm{D}_{2} \mathrm{O}$ (9:1). Multiplicities are quoted as singlet (s), doublet (d), or multiplet $(\mathrm{m})$. Spectra were assigned by using COSY and HSQC. All chemical shifts $(\delta)$ were recorded in ppm and coupling constants $(J)$ are reported in $\mathrm{Hz}$. High-resolution electrospray mass (ESI) spectra were recorded on a microTOF-Q-Bruker spectrometer; accurate mass measurements were achieved by using sodium formate as an external reference. UV/Vis spectra were recorded in approximately $10^{-5} \mathrm{M}$ solutions in DMSO by using an OceanOptics USB4000UV-Vis spectrometer and quartz cells ( $1 \mathrm{~cm}$ path length). Luminiscence measurements were recorded with same solutions by using a Jobin-Yvon-Horiba Fluorolog 3-22 Tau-3 spectrofluorometer.

NMR experiments. NMR experiments were performed with 300 $\mathrm{MHz}$ and $400 \mathrm{MHz}$ spectrometers at $298 \mathrm{~K}$. Magnitude-mode ge-2D COSY spectra were acquired with gradients by using the cosygpqf pulse program with a pulse width of $90^{\circ}$. Phasesensitive ge-2D HSQC spectra were acquired by using z-filter and selection before $\mathrm{t} 1$ removing the decoupling during the acquisition by use of the invigpndph pulse program with CNST2 $(\mathrm{JHC})=145$.

2D-NOESY experiments. NOESY experiments were recorded with a Bruker Avance $400 \mathrm{MHz}$ spectrometer at $298 \mathrm{~K}$ and pH 6.0-6.5 in $\mathrm{H}_{2} \mathrm{O} / \mathrm{D}_{2} \mathrm{O}$ (9:1). The experiments were conducted by using phase-sensitive ge-2D NOESY with WATERGATE for $\mathrm{H}_{2} \mathrm{O} / \mathrm{D}_{2} \mathrm{O}$ (9:1) spectra. NOEs intensities were normalized with respect to 
the diagonal peak at zero mixing time. Distances involving $\mathrm{NH}$ protons were semi-quantitatively determined by integrating the volume of the corresponding cross-peaks. The number of scans used was 16 and the mixing time was $500 \mathrm{~ms}$.

General protocol for microwave-assisted solid-phase peptide synthesis (MW-SPPS). Rink Amide MBHA resin (0.05 or 0.10 mmol) was dwelled with $\mathrm{N}, \mathrm{N}$-dimethylformamide for $5 \mathrm{~min}$. DIC/Oxyma Pure ${ }^{\circledR}$ were used as coupling agents, a $20 \%(\mathrm{v} / \mathrm{v})$ solution of piperidine in DMF for Fmoc deprotection, and a 1:2 mixture of acetic anhydride and pyridine for the final acetylation. Natural Fmoc-protected amino acids (5 equiv.) were coupled using the standard protocol. Sulfamidate building block 1 (5.0 equiv.) was coupled using Oxyma Pure ${ }^{\circledR}$ (5.5 equiv.), DIC (20.0 equiv.) in DMF $(2 \mathrm{~mL})$ under microwave at $75^{\circ} \mathrm{C}$ for 20 min. Chlorambucil and biotin were manually coupled using TBTU and DIPEA in DMF at $-20{ }^{\circ} \mathrm{C}$ for $45 \mathrm{~min}$. Peptides were detached from the resin and acid-sensitive sidechain protecting groups by using a solution of TFA/TIS $/ \mathrm{H}_{2} \mathrm{O}(95: 2.5: 2.5)$ for $3 \mathrm{~h}$ at $25{ }^{\circ} \mathrm{C}$. Peptides were then precipitated with cold diethyl ether and centrifuged, to afford the crude derivatives. Reaction crudes were analysed using a Waters 1525 HPLC system equipped with a diode array detector $(210 / 254 \mathrm{~nm})$ using the analytical column Phenomenex Luna ${ }^{\circledR} \mathrm{C} 18$ (2) column (5 $\mu \mathrm{m}, 250$ $\mathrm{mm} \times 4.6 \mathrm{~mm}$ ) with a flow rate of $1.0 \mathrm{~mL} / \mathrm{min}$ (linear gradient 5$95 \%$ B over $60 \mathrm{~min}$ ). Peptides were purified using a Waters 2695 HPLC system equipped with a dual absorbance detector $(210 / 254 \mathrm{~nm})$ and the semi-preparative column Phenomenex Luna C18(2) $(10 \mu \mathrm{m}, 250 \mathrm{~mm} \times 21.2 \mathrm{~mm})$ with a flow rate of 10 $\mathrm{mL} / \mathrm{min}$ and immediately lyophilised an stored at $-20{ }^{\circ} \mathrm{C}$. Method A: linear gradient 1-31\% B over $30 \mathrm{~min}$. Method B: linear gradient 1-61\% B over $60 \mathrm{~min}$. Method C: linear gradient $5-25 \%$ B over 5 min followed by linear gradient $25-50 \%$ over 25 min. Method D: linear gradient $5-30 \%$ B over 25 min. A: $\mathrm{H}_{2} \mathrm{O}+$ $0.1 \%$ TFA. B: MeCN. Global yields (\%) were calculated as mmo of pure peptide divided by $\mathrm{mmol}$ of resin labelling content (0.63$0.56 \mathrm{mmol} / \mathrm{g}$ loading) and include all amino acid couplings, Fmoc-deprotections, ring-opening reactions, protecting groups/resin cleavage and HPLC purification.

Sulfamidate 1 was synthesized following the methodology previously described by us. ${ }^{67}$

Peptide 2 (1-Ala-Pro-Asp-Thr-Arg-Pro- $\mathrm{NH}_{2}$ ) was synthesized and purified (method A) following the general protocol described above in a $62 \%$ global yield. Semi-preparative HPLC retention time: $25.33 \mathrm{~min}$. HRMS (ESI) $\mathrm{m} / \mathrm{z}=840.3290$, calculated for $\mathrm{C}_{31} \mathrm{H}_{51} \mathrm{~N}_{11} \mathrm{O}_{13} \mathrm{SNa}\left(\mathrm{M}+\mathrm{Na}^{+}\right)=840.3281 .{ }^{1} \mathrm{H} \mathrm{NMR}\left(300 \mathrm{MHz}, \mathrm{D}_{2} \mathrm{O}\right)$ $\delta$ (ppm): 1.08 (d, $3 \mathrm{H}, J=6.4 \mathrm{~Hz}, \mathrm{CH}_{3}$ of Thr), 1.31 (d, $3 \mathrm{H}, \mathrm{J}=7.1$ $\mathrm{Hz}, \mathrm{CH}_{3}$ of Ala), 1.51-1.67 (m, $6 \mathrm{H}, \mathrm{CH}_{3}$ of $1, \mathrm{H}$ of $\mathrm{Arg}, \mathrm{H} \beta$ of $\mathrm{Arg}$ ), 1.68-2.01 (m, 7H, $\mathrm{H} \beta$ of Arg, $\mathrm{H} \beta$ of Pro1, $\mathrm{H} \beta$ of Pro2, $\mathrm{H} \gamma$ of Pro1, $\mathrm{H} \gamma$ of Pro2), 2.12-2.28 (m, $2 \mathrm{H}, \mathrm{H} \beta$ of Pro1, $\mathrm{H} \beta$ of Pro2), 2.71$2.96(\mathrm{~m}, 2 \mathrm{H}, \mathrm{H} \beta$ of Asp), 3.04-3.17 (m, 2H, $\mathrm{H} \delta$ of Arg), 3.45-3.62 $\left(\mathrm{m}, 3 \mathrm{H}, \mathrm{CH}_{2}\right.$ of $1, \mathrm{H} \delta$ of Pro1, $\mathrm{H} \delta$ of Pro2), 3.63-3.76 $(\mathrm{m}, 2 \mathrm{H}, \mathrm{H} \delta$ of Pro1, $\mathrm{H} \delta$ of Pro2), 3.81 (d, $1 \mathrm{H}, J=12.8 \mathrm{~Hz}, \mathrm{CH}_{2}$ of 1 ), 4.05-4.14 ( $m, 1 \mathrm{H}, \mathrm{H} \beta$ of Thr), 4.19-4.35 (m, 3H, $\mathrm{H} \alpha$ of Pro1, $\mathrm{H} \alpha$ of Pro2, $\mathrm{H} \alpha$ of Thr), 4.48-4.66 (m, 3H, $\mathrm{H} \alpha$ of Ala, $\mathrm{H} \alpha$ of Arg, $\mathrm{H} \alpha$ of Asp). ${ }^{13} \mathrm{C}$ NMR (75 MHz, $\left.\mathrm{D}_{2} \mathrm{O}\right) \delta$ (ppm): 15.1 ( $\mathrm{CH}_{3}$ of Ala), $18.8\left(\mathrm{CH}_{3}\right.$ of Thr), $22.5\left(\mathrm{CH}_{3}\right.$ of 1), 24.0 ( $\mathrm{C} \gamma$ of $\left.\mathrm{Arg}\right), 24.6$ ( $\mathrm{C}_{\gamma}$ of Pro1), 24.7 ( $\mathrm{C}_{\gamma}$ of
Pro2), 27.5 ( $C \beta$ of $A r g$ ), 29.2 ( $C \beta$ of Pro1), 29.5 ( $C \beta$ of Pro2), 34.9

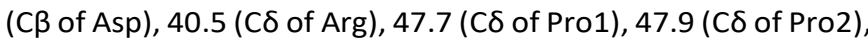
48.3 (C $\alpha$ of Ala), 50.1 (C $\alpha$ of Asp), 51.1 (C $\alpha$ of Arg), $51.2\left(\mathrm{CH}_{2}\right.$ of 1), 59.0 ( $\mathrm{C} \alpha$ of Thr), 60.2 (C $\alpha$ of Pro2), 60.7 ( $C \alpha$ of Pro1), 67.1 (C $\beta$ of Thr), 90.2 (C $\alpha$ of 1), 156.7 ( $\mathrm{HN}=\mathrm{C}$ of Arg), 171.3, 171.3, 171.4, $172.4,172.6,174.0,176.8$ (CO).

Peptide 3 (Ac-1-Ala-Pro-Asp-Thr-Arg-Pro- $\mathrm{NH}_{2}$ ) was synthesized and purified (method $A$ ) following the general protocol described above in a 78\% global yield. Semi-preparative HPLC retention time: $26.92 \mathrm{~min}$. HRMS (ESI) $\mathrm{m} / \mathrm{z}=860.3561$, calculated for $\mathrm{C}_{33} \mathrm{H}_{54} \mathrm{~N}_{11} \mathrm{O}_{14} \mathrm{~S}[\mathrm{M}+\mathrm{H}]^{+}=860.3567 .{ }^{1} \mathrm{H}$ NMR $(300$ $\mathrm{MHz}, \mathrm{D}_{2} \mathrm{O}$ ) $\delta$ (ppm): 1.05 (d, $3 \mathrm{H}, J=6.4 \mathrm{~Hz}, \mathrm{CH}_{3}$ of Thr), 1.27 (d, $3 \mathrm{H}, J=7.1 \mathrm{~Hz}, \mathrm{CH}_{3}$ of Ala), 1.47-1.63 (m, 3H, Hy of Arg, $\mathrm{H} \beta$ of Arg), 1.65-1.93 (m, 10H, $\mathrm{CH}_{3}$ of $1, \mathrm{H} \beta$ of Arg, $\mathrm{H} \beta$ of Pro1, $\mathrm{H} \beta$ of Pro2, $\mathrm{H} \gamma$ of Pro1, $\mathrm{H} \gamma$ of Pro2), 2.07-2.27 (m, 5H, Ac, $\mathrm{H} \beta$ of Pro1, $\mathrm{H} \beta$ of Pro2), 2.71-2.90 (m, $2 \mathrm{H}, \mathrm{H} \beta$ of Asp), 3.01-3.13 (m, $2 \mathrm{H}, \mathrm{H} \delta$ of Arg), 3.43-3.72 (m, $4 \mathrm{H}, \mathrm{H} \delta$ of Pro1, $\mathrm{H} \delta$ of Pro2), 4.02-4.14 (m, $2 \mathrm{H}, \mathrm{CH}_{2}$ of $1, \mathrm{H} \beta$ of Thr), 4.16-4.31 (m, 3H, $\mathrm{H} \alpha$ of Pro1, $\mathrm{H} \alpha$ of Pro2, $\mathrm{H} \alpha$ of Thr), 4.47 (d, $1 \mathrm{H}, J=10.5 \mathrm{~Hz}, \mathrm{CH}_{2}$ of 1 ), 4.50-4.65 (m, $3 \mathrm{H}, \mathrm{H} \alpha$ of Ala, $\mathrm{H} \alpha$ of Arg, $\mathrm{H} \alpha$ of Asp). ${ }^{13} \mathrm{C}$ NMR $\left(75 \mathrm{MHz}, \mathrm{D}_{2} \mathrm{O}\right) \delta$ (ppm): 15.1 ( $\mathrm{CH}_{3}$ of Ala), $18.8\left(\mathrm{CH}_{3}\right.$ of Thr), 22.2 (Ac), $22.5\left(\mathrm{CH}_{3}\right.$ of 1), 23.9 ( $C_{\gamma}$ of $\mathrm{Arg}$ ), 24.6 ( $C_{\gamma}$ of Pro1, $C_{\gamma}$ of Pro2), 27.4 (CB of Arg), 29.2 ( $C \beta$ of Pro1), 29.5 ( $C \beta$ of Pro2), 34.9 ( $C \beta$ of $A s p$ ), 40.5 ( $\mathrm{C} \delta$ of Arg), 47.7 ( $\mathrm{C} \delta$ of Pro1), 47.8 (C $\delta$ of Pro2), 48.3 ( $\mathrm{C} \alpha$ of Ala), 50.1 ( $\mathrm{C} \alpha$ of Asp), 51.1 ( $\mathrm{C} \alpha$ of $\mathrm{Arg}$ ), 52.7 ( $\mathrm{CH}_{2}$ of 1 ), 59.0 ( $\mathrm{C} \alpha$ of Thr), 60.2 (C $\alpha$ of Pro2), 60.7 (C $\alpha$ of Pro1), 66.9 (C $\beta$ of Thr), 90.1 (C $\alpha$ of 1), 156.6 (HN=C of Arg), 169.2, 171.3, 172.2, 172.3, 172.4, $172.5,173.9,176.7$ (CO).

Peptide 4 (Ac- $\beta$ Aiba $\left(\mathrm{N}_{3}\right.$ )-Ala-Pro-Asp-Thr-Arg-Pro- $\mathrm{NH}_{2}$ ) [ $\beta$ Aiba $=$ beta-aminoisobutyric acid] was synthesized by reacting resinlinked peptide 3 ( $0.05 \mathrm{mmol}$ of resin) with 20 equiv. of sodium azide in DMF at room temperature for $3 \mathrm{~h}$. After that time, the resin was washed with DMF $(5 \times 3 \mathrm{~mL})$ and $\mathrm{CH}_{2} \mathrm{Cl}_{2}(5 \times 3 \mathrm{~mL})$, treated with the cleavage cocktail, precipitated, and purified (method A) as described in the general method (31\% global yield). Semi-preparative HPLC retention time: $23.39 \mathrm{~min}$. HRMS (ESI) $\mathrm{m} / \mathrm{z}=823.4161$, calculated for $\mathrm{C}_{33} \mathrm{H}_{55} \mathrm{~N}_{14} \mathrm{O}_{11}[\mathrm{M}+\mathrm{H}]^{+}=$ 823.4169. ${ }^{1} \mathrm{H}$ NMR $\left(300 \mathrm{MHz}, \mathrm{D}_{2} \mathrm{O}\right) \delta(\mathrm{ppm}): 1.11(\mathrm{~d}, 3 \mathrm{H}, J=6.4$ $\mathrm{Hz}, \mathrm{CH}_{3}$ of Thr), 1.31 (d, 3H, J = $7.1 \mathrm{~Hz}, \mathrm{CH}_{3}$ of Ala), $1.44(\mathrm{~s}, 3 \mathrm{H}$, $\mathrm{CH}_{3}$ of $\beta$ Aiba), 1.52-2.04 (m, 13H, $\mathrm{H}$ of Arg, $\mathrm{H} \beta$ of Arg, $\mathrm{H} \beta$ of Pro1, $\mathrm{H} \beta$ of Pro2, $\mathrm{H} \gamma$ of Pro1, $\mathrm{H} \gamma$ of Pro2, Ac), 2.14-2.32 (m, $2 \mathrm{H}$, $\mathrm{H} \beta$ of Pro1, $\mathrm{H} \beta$ of Pro2), 2.75-2.98 (m, $2 \mathrm{H}, \mathrm{H} \beta$ of Asp), 3.10-3.18 (m, $2 \mathrm{H}, \mathrm{H} \delta$ of Arg), 3.40 (d, $1 \mathrm{H}, J=14.2 \mathrm{~Hz}, \mathrm{CH}_{2}$ of $\beta$ Aiba), 3.48$3.80\left(\mathrm{~m}, 5 \mathrm{H}, \mathrm{H} \delta\right.$ of Pro1, $\mathrm{H} \delta$ of Pro2, $\mathrm{CH}_{2}$ of $\beta$ Aiba), 4.08-4.19 (m, $1 \mathrm{H}, \mathrm{H} \beta$ of Thr), 4.20-4.39 (m, 3H, $\mathrm{H} \alpha$ of Pro1, $\mathrm{H} \alpha$ of Pro2, $\mathrm{H} \alpha$ of Thr), 4.43-4.67 (m, 3H, H $\alpha$ of Ala, $\mathrm{H} \alpha$ of Arg, $\mathrm{H} \alpha$ of Asp). ${ }^{13} \mathrm{C}$ NMR (75 MHz, $\left.\mathrm{D}_{2} \mathrm{O}\right) \delta$ (ppm): $15.2\left(\mathrm{CH}_{3}\right.$ of Ala), $18.8\left(\mathrm{CH}_{3}\right.$ of Thr), 19.0 ( $\mathrm{CH}_{3}$ of $\beta$ Aiba), 21.8 (Ac), 24.0 ( $\mathrm{C} \gamma$ of $\mathrm{Arg}$ ), 24.6 ( $\mathrm{C} \gamma$ of Pro1), 24.7 ( $C \gamma$ of Pro2), 27.4 ( $C \beta$ of $A r g$ ), 29.3 (C $\beta$ of Pro1), 29.6 ( $C \beta$ of Pro2), 35.0 (C $\beta$ of Asp), 40.5 ( $C \delta$ of $A r g$ ), $45.4\left(\mathrm{CH}_{2}\right.$ of $\beta$ Aiba), 47.8 (C $\delta$ of Pro1), 47.9 (C $\delta$ of Pro2), 48.2 ( $\mathrm{C} \alpha$ of Ala), 50.1 ( $\mathrm{C} \alpha$ of Asp), 51.1 ( $\mathrm{C} \alpha$ of Arg), 59.0 (C $\alpha$ of Thr), 60.3 (C $\alpha$ of Pro2), 60.6 ( $\mathrm{C} \alpha$ of Pro1), 67.0 ( $\mathrm{C} \beta$ of Thr), 118.2 (C $\alpha$ of $\beta$ Aiba), 156.7 (HN=C of $\mathrm{Arg}$ ), 171.3, 171.4, 172.4, 172.5, 173.0, 174.0, 174.4, 176.8 (CO). 
Peptide APDTRP (Ac-Ala-Pro-Asp-Thr-Arg-Pro- $\mathrm{NH}_{2}$ ) was obtained as a by-product in the synthesis of peptide 4 . Semipreparative HPLC retention time (Method A): $19.10 \mathrm{~min}$. MS (ESI) $\mathrm{m} / \mathrm{z}=697.3$, calculated for $\mathrm{C}_{29} \mathrm{H}_{49} \mathrm{~N}_{10} \mathrm{O}_{10}[\mathrm{M}+\mathrm{H}]^{+}=$ 697.3628. ${ }^{1} \mathrm{H}$ NMR (300 MHz, $\left.\mathrm{D}_{2} \mathrm{O}\right) \delta(\mathrm{ppm}): 1.11(\mathrm{~d}, 3 \mathrm{H}, J=6.3$ $\mathrm{Hz}, \mathrm{CH}_{3}$ of Thr), 1.28 (d, 3H, J = 7.1 Hz, $\mathrm{CH}_{3}$ of Ala), 1.53-2.10 (m, $13 \mathrm{H}, \mathrm{H} \gamma$ of $\mathrm{Arg}, \mathrm{H} \beta$ of $\mathrm{Arg}, \mathrm{H} \beta$ of Pro1, $\mathrm{H} \beta$ of Pro2, $\mathrm{H} \gamma$ of Pro1, $\mathrm{H} \gamma$ of Pro2, Ac), 2.14-2.31 (m, $2 \mathrm{H}, \mathrm{H} \beta$ of Pro1, $\mathrm{H} \beta$ of Pro2), 2.75-2.94 (m, $2 \mathrm{H}, \mathrm{H} \beta$ of Asp), 3.10-3.18 (m, $2 \mathrm{H}, \mathrm{H} \delta$ of Arg), 3.48-3.81 (m, $4 \mathrm{H}, \mathrm{H} \delta$ of Pro1, $\mathrm{H} \delta$ of Pro2), 4.09-4.20 ( $\mathrm{m}, 1 \mathrm{H}, \mathrm{H} \beta$ of Thr), 4.204.39 (m, 3H, $\mathrm{H} \alpha$ of Pro1, $\mathrm{H} \alpha$ of Pro2, $\mathrm{H} \alpha$ of Thr), 4.43-4.68 (m, $3 \mathrm{H}, \mathrm{H} \alpha$ of Ala, $\mathrm{H} \alpha$ of Arg, $\mathrm{H} \alpha$ of Asp).

Peptides $\mathbf{5 a}$ and $\mathbf{5 b}$ (Ac- $\beta$ Aiba(BCN-triazol)-Ala-Pro-Asp-ThrArg-Pro- $-\mathrm{NH}_{2}$ ) were synthesized by reacting peptide 4 with 2 equiv. of bicycle[6.1.0]non-4-yn-9-ylmethanol ( $\mathrm{BCN}-\mathrm{OH})$ in a $1: 3$ mixture of $\mathrm{H}_{2} \mathrm{O}$ and $\mathrm{MeCN}$ at room temperature for $2 \mathrm{~h}$, and purified using method B (77\% combined yield). Semipreparative HPLC retention times: 18.60 and $20.00 \mathrm{~min}$, respectively. HRMS (ESI) $\mathrm{m} / \mathrm{z}=973.5200$ and 973.5211, calculated for $\mathrm{C}_{43} \mathrm{H}_{68} \mathrm{~N}_{14} \mathrm{O}_{12}[\mathrm{M}+\mathrm{H}]^{+}=973.5214 .{ }^{1} \mathrm{H}$ NMR for $5 \mathrm{a}$ (300 MHz, $\left.\mathrm{D}_{2} \mathrm{O}\right) \delta(\mathrm{ppm}): 1.02-1.13\left(\mathrm{~m}, 5 \mathrm{H}, \mathrm{CH}_{3}\right.$ of $\left.\mathrm{Thr}, \mathrm{H}^{1}, \mathrm{H}^{8}\right)$, 1.16-1.31 (m, $4 \mathrm{H}, \mathrm{CH}_{3}$ of Ala, $\left.\mathrm{H}^{9}\right), 1.46-2.33\left(\mathrm{~m}, 22 \mathrm{H}, \mathrm{CH}_{3}\right.$ of BAiba, $\mathrm{H} \gamma$ of Arg, $\mathrm{H} \beta$ of Arg, $\mathrm{H} \beta$ of Pro1, $\mathrm{H} \beta$ of Pro2, $\mathrm{H} \gamma$ of Pro1, $\mathrm{H} \gamma$ of Pro2, $\left.A c, \mathrm{H}^{2}, \mathrm{H}^{7}\right)$, 2.57-2.97 (m, $6 \mathrm{H}, \mathrm{H} \beta$ of Asp, $\left.\mathrm{H}^{3}, \mathrm{H}^{6}\right)$, 3.08$3.16(\mathrm{~m}, 2 \mathrm{H}, \mathrm{H} \delta$ of $\mathrm{Arg}), 3.50-3.81(\mathrm{~m}, 7 \mathrm{H}, \mathrm{H} \delta$ of Pro1, $\mathrm{H} \delta$ of Pro2, $\mathrm{CH}_{2}$ of $\beta$ Aiba, $\left.\mathrm{H}^{10}\right), 3.98\left(\mathrm{~d}, 1 \mathrm{H}, J=14.4 \mathrm{~Hz}, \mathrm{CH}_{2}\right.$ of $\beta$ Aiba), 4.05$4.13(\mathrm{~m}, 1 \mathrm{H}, \mathrm{H} \beta$ of $\mathrm{Thr}), 4.18-4.36(\mathrm{~m}, 3 \mathrm{H}, \mathrm{H} \alpha$ of Pro1, $\mathrm{H} \alpha$ of Pro2, $\mathrm{H} \alpha$ of Thr), 4.42-4.67 (m, 3H, H $\alpha$ of Ala, $\mathrm{H} \alpha$ of Arg, H $\alpha$ of Asp). ${ }^{1} \mathrm{H}$ NMR for $5 \mathbf{b}\left(300 \mathrm{MHz}, \mathrm{D}_{2} \mathrm{O}\right) \delta(\mathrm{ppm})$ : 0.71-0.90 $\left(\mathrm{H}^{1}, \mathrm{H}^{8}\right)$, 0.95$1.12\left(\mathrm{~m}, 4 \mathrm{H}, \mathrm{CH}_{3}\right.$ of $\left.\mathrm{Thr}, \mathrm{H}^{9}\right), 1.22\left(\mathrm{~d}, 3 \mathrm{H}, J=7.1 \mathrm{~Hz}, \mathrm{CH}_{3}\right.$ of Ala), 1.43-2.29 (m, 22H, $\mathrm{CH}_{3}$ of $\beta$ Aiba, $\mathrm{H} \gamma$ of Arg, $\mathrm{H} \beta$ of Arg, $\mathrm{H} \beta$ of Pro1, $\mathrm{H} \beta$ of Pro2, $\mathrm{H} \gamma$ of Pro1, $\mathrm{H} \gamma$ of Pro2, $\left.\mathrm{Ac}, \mathrm{H}^{2}, \mathrm{H}^{7}\right), 2.51-2.96$ $\left(\mathrm{m}, 6 \mathrm{H}, \mathrm{H} \beta\right.$ of Asp, $\left.\mathrm{H}^{3}, \mathrm{H}^{6}\right)$, 3.08-3.16 (m, $2 \mathrm{H}, \mathrm{H} \delta$ of Arg), 3.48$3.83\left(\mathrm{~m}, 7 \mathrm{H}, \mathrm{H} \delta\right.$ of Pro1, $\mathrm{H} \delta$ of Pro2, $\mathrm{CH}_{2}$ of $\beta$ Aiba, $\left.\mathrm{H}^{10}\right), 3.99(\mathrm{~d}$, $1 \mathrm{H}, J=14.5 \mathrm{~Hz}, \mathrm{CH}_{2}$ of $\beta$ Aiba), 4.05-4.14 (m, $1 \mathrm{H}, \mathrm{H} \beta$ of Thr), 4.17$4.37(\mathrm{~m}, 3 \mathrm{H}, \mathrm{H} \alpha$ of Pro1, $\mathrm{H} \alpha$ of Pro2, $\mathrm{H} \alpha$ of Thr), 4.50-4.64 (m, $3 \mathrm{H}, \mathrm{H} \alpha$ of Ala, $\mathrm{H} \alpha$ of Arg, $\mathrm{H} \alpha$ of Asp).

Peptide 7 (Ac-BAiba(Coum)-Ala-Pro-Asp-Thr-Arg-Pro- $\mathrm{NH}_{2}$ ) was synthesized by reacting resin-linked peptide $3(0.05 \mathrm{mmol}$ of resin) with 10 equiv. of 7-mercapt-4-methylcoumarin 6 and 9 equiv. of DIPEA in DMF at room temperature for $1.5 \mathrm{~h}$. After that time, the resin was washed with DMF $(5 \times 3 \mathrm{~mL})$ and $\mathrm{CH}_{2} \mathrm{Cl}_{2}(5 \times$ $3 \mathrm{~mL}$ ), treated with the cleavage cocktail, precipitated, and purified (method C) as described in the general method $(45 \%$ global yield). Semi-preparative HPLC retention time: $16.47 \mathrm{~min}$. HRMS (ESI) $\mathrm{m} / \mathrm{z}=972.4244$, calculated for $\mathrm{C}_{43} \mathrm{H}_{62} \mathrm{~N}_{11} \mathrm{O}_{13} \mathrm{~S}[\mathrm{M}+\mathrm{H}]^{+}$ $=972.4244 .{ }^{1} \mathrm{H}$ NMR $\left(300 \mathrm{MHz}, \mathrm{D}_{2} \mathrm{O}\right) \delta(\mathrm{ppm}): 1.09(\mathrm{~d}, 3 \mathrm{H}, J=6.4$ $\mathrm{Hz}, \mathrm{CH}_{3}$ of Thr), 1.27 (d, 3H, J=7.0 Hz, $\mathrm{CH}_{3}$ of Ala), 1.35 (s, 3H, $\mathrm{CH}_{3}$ of $\beta$ Aiba), 1.45-2.04 (m, 13H, $\mathrm{H} \gamma$ of Arg, $\mathrm{H} \beta$ of Arg, $\mathrm{H} \beta$ of Pro1, $\mathrm{H} \beta$ of Pro2, $\mathrm{H} \gamma$ of Pro1, $\mathrm{H} \gamma$ of Pro2, Ac), 2.13-2.30 (m, $2 \mathrm{H}$, $\mathrm{H} \beta$ of Pro1, $\mathrm{H} \beta$ of Pro2), 2.36 (s, 3H, $\mathrm{CH}_{3}$ of Coum), 2.77-2.96 (m, $2 \mathrm{H}, \mathrm{H} \beta$ of Asp), 3.00-3.14 (m, $2 \mathrm{H}, \mathrm{H} \delta$ of $\mathrm{Arg}), 3.46-3.75(\mathrm{~m}, 6 \mathrm{H}$, $\mathrm{H} \delta$ of Pro1, $\mathrm{H} \delta$ of Pro2, $\mathrm{CH}_{2}$ of $\beta$ Aiba), 4.05-4.17 (m, $1 \mathrm{H}, \mathrm{H} \beta$ of Thr), 4.21-4.67 (m, 6H, $\mathrm{H} \alpha$ of Pro1, $\mathrm{H} \alpha$ of Pro2, $\mathrm{H} \alpha$ of Thr, $\mathrm{H} \alpha$ of Ala, $\mathrm{H} \alpha$ of Arg, $\mathrm{H} \alpha$ of Asp), $6.30\left(\mathrm{~s}, 1 \mathrm{H}, \mathrm{H}^{3}\right), 7.24-7.40\left(\mathrm{~m}, 2 \mathrm{H}, \mathrm{H}^{6}\right.$, $\left.\mathrm{H}^{8}\right), 7.62\left(\mathrm{~d}, 1 \mathrm{H}, J=9.1 \mathrm{~Hz}, \mathrm{H}^{5}\right) .{ }^{13} \mathrm{C} \mathrm{NMR}\left(75 \mathrm{MHz}, \mathrm{D}_{2} \mathrm{O}\right) \delta(\mathrm{ppm})$ :
$15.3\left(\mathrm{CH}_{3}\right.$ of Ala $), 17.9\left(\mathrm{CH}_{3}\right.$ of Coum $), 18.8\left(\mathrm{CH}_{3}\right.$ of Thr $), 21.0$ ( $\mathrm{CH}_{3}$ of $\beta$ Aiba), 21.8 (Ac), 24.0 ( $\mathrm{C} \gamma$ of $\mathrm{Arg}$ ), 24.6 ( $\mathrm{C} \gamma$ of Pro1), 24.7 ( $C \gamma$ of Pro2), 27.5 ( $C \beta$ of Arg), 29.3 ( $C \beta$ of Pro1), 29.6 ( $C \beta$ of Pro2), 34.9 ( $\mathrm{C} \beta$ of Asp), 40.5 ( $\mathrm{C} \delta$ of $\mathrm{Arg}$ ), $45.5\left(\mathrm{CH}_{2}\right.$ of $\beta$ Aiba), 47.8 ( $\mathrm{C} \delta$ of Pro1), 47.9 ( $\mathrm{C} \delta$ of Pro2), 48.3 ( $\mathrm{C} \alpha$ of Ala), 50.1 ( $\mathrm{C} \alpha$ of Asp), 51.0 ( $\mathrm{C} \alpha$ of Arg), 55.9 (C $\alpha$ of $\beta$ Aiba), 59.1 (C $\alpha$ of Thr), 60.2 (C $\alpha$ of Pro2), 60.6 (C $\alpha$ of Pro1), 67.1 (C $\beta$ of Thr), $114.4\left(C^{3}\right), 120.5$ $\left(C^{4 a}\right), 122.8\left(C^{8}\right), 125.6\left(C^{5}\right), 131.4\left(C^{6}\right), 134.5\left(C^{7}\right), 152.1\left(C^{8 a}\right)$, $155.4\left(\mathrm{C}^{4}\right), 156.6(\mathrm{HN}=\mathrm{C}$ of $\mathrm{Arg}), 163.6\left(\mathrm{C}^{2}\right), 171.2,171.3,172.5$, $172.9,173.5,174.0,174.3,176.7$ (CO).

Peptide 9 ( $\mathrm{HSO}_{3}$ - $\beta$ Aiba( $\beta$ Glc-S)-Ala-Pro-Asp-Thr-Arg-Pro- $\mathrm{NH}_{2}$ ) was synthesized by reacting resin-linked peptide $\mathbf{3}(0.05 \mathrm{mmol}$ of resin) with 10 equiv. of tetra- $O$-acetyl- $\beta$-thioglucose 8 and 9 equiv. of DIPEA in DMF at room temperature for $1.5 \mathrm{~h}$. After that time, the resin was washed with DMF $(5 \times 3 \mathrm{~mL})$ and methanol $(5 \times 3 \mathrm{~mL})$ and treated with a 70\% solution of hydrazine in methanol ( $3 \times 45 \mathrm{~min})$. Then, the resin was washed with methanol $(5 \times 3 \mathrm{~mL})$, DMF $(5 \times 3 \mathrm{~mL})$ and $\mathrm{CH}_{2} \mathrm{Cl}_{2}(5 \times 3 \mathrm{~mL})$, treated with the cleavage cocktail, precipitated, and purified (method A) as described in the general method (16\% global yield). Semi-preparative HPLC retention time: $19.77 \mathrm{~min}$. HRMS (ESI) $\mathrm{m} / \mathrm{z}=1014.3829$, calculated for $\mathrm{C}_{37} \mathrm{H}_{64} \mathrm{~N}_{11} \mathrm{O}_{18} \mathrm{~S}_{2}[\mathrm{M}+\mathrm{H}]^{+}=$ 1014.3867. ${ }^{1} \mathrm{H}$ NMR (400 MHz, $\left.\mathrm{D}_{2} \mathrm{O}\right) \delta(\mathrm{ppm}): 1.08$ (d, $3 \mathrm{H}, J=6.4$ $\mathrm{Hz}, \mathrm{CH}_{3}$ of Thr), 1.29 (d, $3 \mathrm{H}, J=7.1 \mathrm{~Hz}, \mathrm{CH}_{3}$ of Ala), 1.46 (s, $3 \mathrm{H}$, $\mathrm{CH}_{3}$ of $\beta$ Aiba), $1.50-2.00(\mathrm{~m}, 10 \mathrm{H}, \mathrm{H} \gamma$ of Arg, $\mathrm{H} \beta$ of Arg, $\mathrm{H} \beta$ of Pro1, $\mathrm{H} \beta$ of Pro2, $\mathrm{H} \gamma$ of Pro1, $\mathrm{H} \gamma$ of Pro2), 2.12-2.23 (m, $2 \mathrm{H}, \mathrm{H} \beta$ of Pro1, $\mathrm{H} \beta$ of Pro2), 2.74-2.92 (m, $2 \mathrm{H}, \mathrm{H} \beta$ of Asp), 3.04-3.32 (m, $7 \mathrm{H}, \mathrm{H} \delta$ of $\left.\mathrm{Arg}, \mathrm{H}^{2}, \mathrm{H}^{4}, \mathrm{H}^{5}, \mathrm{H}^{6}\right), 3.36-3.44\left(\mathrm{~m}, 1 \mathrm{H}, \mathrm{H}^{3}\right), 3.46-3.79$ ( $m, 6 \mathrm{H}, \mathrm{H} \delta$ of Pro1, $\mathrm{H} \delta$ of Pro2, $\mathrm{CH}_{2}$ of $\beta$ Aiba) , 4.05-4.16 (m, $1 \mathrm{H}$, $\mathrm{H} \beta$ of Thr), 4.17-4.34 (m, 3H, $\mathrm{H} \alpha$ of Pro1, $\mathrm{H} \alpha$ of Pro2, $\mathrm{H} \alpha$ of Thr), 4.40-4.64 (m, 4H, $\mathrm{H} \alpha$ of Ala, $\mathrm{H} \alpha$ of Arg, $\mathrm{H} \alpha$ of Asp, $\left.\mathrm{H}^{1}\right) .{ }^{13} \mathrm{C} N M R$ (75 MHz, $\left.\mathrm{D}_{2} \mathrm{O}\right) \delta$ (ppm): $15.0\left(\mathrm{CH}_{3}\right.$ of Ala), $18.8\left(\mathrm{CH}_{3}\right.$ of Thr), 22.1 ( $\mathrm{CH}_{3}$ of $\beta$ Aiba), 24.0 ( $\mathrm{C} \gamma$ of Arg), 24.6 ( $\mathrm{C} \gamma$ of Pro1, $\mathrm{C} \gamma$ of Pro2), 27.3 (C $\beta$ of $A r g$ ), 29.2 ( $C \beta$ of Pro1), 29.5 ( $C \beta$ of Pro2), 35.0 ( $C \beta$ of Asp), 40.4 ( $C \delta$ of Arg), 47.7 ( $C \delta$ of Pro1), 47.8 (C $\delta$ of Pro2), 48.5 (C $\alpha$ of Ala), $49.4\left(\mathrm{C}^{6}\right), 50.2$ (C $\alpha$ of Asp), 51.0 (C $\alpha$ of Arg), 52.8 (C $\alpha$ of $\beta$ Aiba), 59.0 ( $C \alpha$ of Thr), 60.2 (C $\alpha$ of Pro2, $\mathrm{C} \alpha$ of Pro1), 60.6 ( $\mathrm{CH}_{2}$ of $\beta$ Aiba), 66.9 (C $\beta$ of Thr), $69.1\left(\mathrm{C}^{4}\right), 72.2\left(\mathrm{C}^{2}\right), 77.1\left(\mathrm{C}^{3}\right)$, $79.7\left(C^{5}\right), 83.0\left(C^{1}\right), 156.6(\mathrm{HN}=\mathrm{C}$ of $\mathrm{Arg}), 171.3,171.4,172.6$, 173.3, 174.1, 174.5, 176.8 (CO).

Peptide 10 (Chlorambucil-1-Ala-Pro-Asp-Thr-Arg-Pro-NH $\mathrm{NH}_{2}$ ) was synthesized and purified (method D) following the general protocol described above in a $33 \%$ global yield. Semipreparative HPLC retention time: $52.07 \mathrm{~min}$. HRMS (ESI) $\mathrm{m} / \mathrm{z}=$ 1103.4148, calculated for $\mathrm{C}_{45} \mathrm{H}_{69} \mathrm{Cl}_{2} \mathrm{~N}_{12} \mathrm{O}_{14} \mathrm{~S}[\mathrm{M}+\mathrm{H}]^{+}=1103.4148$. ${ }^{1} \mathrm{H}$ NMR (300 MHz, $\left.\mathrm{D}_{2} \mathrm{O}\right) \delta(\mathrm{ppm}): 1.08\left(\mathrm{~d}, 3 \mathrm{H}, J=6.3 \mathrm{~Hz}, \mathrm{CH}_{3}\right.$ of Thr), 1.31 (d, $3 \mathrm{H}, J=7.0 \mathrm{~Hz}, \mathrm{CH}_{3}$ of Ala), 1.51-2.01 (m, 15H, $\mathrm{CH}_{3}$ of $1, H \gamma$ of $A r g, H \beta$ of Arg, $H \beta$ of Pro1, $H \beta$ of Pro2, $H \gamma$ of Pro1, $H \gamma$ of Pro2, $\mathrm{H} \beta$ of chlorambucil), 2.08-2.31 (m, $2 \mathrm{H}, \mathrm{H} \beta$ of Pro1, $\mathrm{H} \beta$

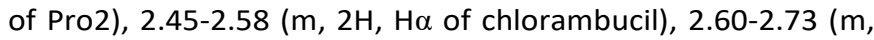
$2 \mathrm{H}, \mathrm{H} \gamma$ of chlorambucil), 2.74-2.96 (m, $2 \mathrm{H}, \mathrm{H} \beta$ of Asp), 3.05-3.15 $(\mathrm{m}, 2 \mathrm{H}, \mathrm{H} \delta$ of $\mathrm{Arg}), 3.45-3.77\left(\mathrm{~m}, 8 \mathrm{H}, \mathrm{H} \delta\right.$ of Pro1, $\mathrm{H} \delta$ of Pro2, $\left.\mathrm{H}^{1}\right)$, 3.92-4.02 $\left(\mathrm{m}, 4 \mathrm{H}, \mathrm{H}^{2}\right), 4.03-4.16\left(\mathrm{~m}, 2 \mathrm{H}, \mathrm{CH}_{2}\right.$ of $1, \mathrm{H} \beta$ of $\left.\mathrm{Thr}\right)$, 4.17-4.35 (m, 3H, $\mathrm{H} \alpha$ of Pro1, $\mathrm{H} \alpha$ of Pro2, $\mathrm{H} \alpha$ of Thr), 4.43-4.66 (m, $4 \mathrm{H}, \mathrm{CH}_{2}$ of $1, \mathrm{H} \alpha$ of Ala, $\mathrm{H} \alpha$ of Arg, $\mathrm{H} \alpha$ of Asp), 7.36-7.50 (m, $4 \mathrm{H}$, Arom.). ${ }^{13} \mathrm{C}$ NMR (75 MHz, $\left.\mathrm{D}_{2} \mathrm{O}\right) \delta$ (ppm): $15.2\left(\mathrm{CH}_{3}\right.$ of Ala), 
$18.8\left(\mathrm{CH}_{3}\right.$ of Thr), $22.4\left(\mathrm{CH}_{3}\right.$ of 1 ), 24.0 ( $\mathrm{C} \gamma$ of $\mathrm{Arg}$ ), 24.6 ( $\mathrm{C} \gamma$ of Pro1, $C \gamma$ of Pro2), 25.5 ( $C \beta$ of chlorambucil), 27.4 ( $C \beta$ of $A r g$ ), 29.2 (C $\beta$ of Pro1), 29.5 (C $\beta$ of Pro2), 32.9 ( $C \alpha$ of chlorambucil), 33.5 ( $C \gamma$ of chlorambucil), 34.9 ( $C \beta$ of Asp), 37.2 ( $C^{1}$ ), 40.5 (C $\delta$ of Arg), 47.7 (C $\delta$ of Pro1), 47.9 (C $\delta$ of Pro2), 48.3 (C $\alpha$ of Ala), 50.1 (C $\alpha$ of Asp), 51.1 ( $\mathrm{C} \alpha$ of $\mathrm{Arg}$ ), $52.2\left(\mathrm{CH}_{2}\right.$ of 1), $58.9\left(\mathrm{C}^{2}\right), 59.1$ ( $\mathrm{C} \alpha$ of Thr), 60.2 (C $\alpha$ of Pro2), 60.7 ( $C \alpha$ of Pro1), 67.0 (C $\beta$ of Thr), 86.3 (C $\alpha$ of 1), 122.1, 122.3, 130.7, 133.0, 144.8 (Arom.), 156.7 $(\mathrm{HN}=\mathrm{C}$ of $\mathrm{Arg}), 169.1,171.1,172.1,172.4,173.9,174.0,176.7$ (CO).

Peptide 11 (Biotin-1-Ala-Pro-Asp-Thr-Arg-Pro- $\mathrm{NH}_{2}$ ) was synthesized and purified (method D) following the general protocol described above in a $62 \%$ global yield. Semipreparative HPLC retention time: $31.49 \mathrm{~min}$. HRMS (ESI) $\mathrm{m} / \mathrm{z}=$ 1044.4221, calculated for $\mathrm{C}_{41} \mathrm{H}_{66} \mathrm{~N}_{13} \mathrm{O}_{15} \mathrm{~S}_{2}[\mathrm{M}+\mathrm{H}]^{+}=1044.4237$. ${ }^{1} \mathrm{H}$ NMR (300 MHz, $\left.\mathrm{D}_{2} \mathrm{O}\right) \delta(\mathrm{ppm}): 1.06\left(\mathrm{~d}, 3 \mathrm{H}, J=6.4 \mathrm{~Hz}, \mathrm{CH}_{3}\right.$ of Thr), 1.24-1.37 (m, $6 \mathrm{H}, \mathrm{CH}_{3}$ of Ala, $\mathrm{H} \gamma$ of biotin, $\mathrm{H} \beta$ of biotin), 1.49-1.63 $(\mathrm{m}, 7 \mathrm{H}, \mathrm{H} \beta$ of biotin, $\mathrm{H} \delta$ of biotin, $\mathrm{H} \gamma$ of Arg, $\mathrm{H} \beta$ of Arg), $1.68-1.97\left(m, 10 \mathrm{H}, \mathrm{CH}_{3}\right.$ of $1, \mathrm{H} \beta$ of $\mathrm{Arg}, \mathrm{H} \beta$ of Pro1, $\mathrm{H} \beta$ of Pro2, $\mathrm{H} \gamma$ of Pro1, $\mathrm{H} \gamma$ of Pro2), 2.11-2.26 (m, $2 \mathrm{H}, \mathrm{H} \beta$ of Pro1, $\mathrm{H} \beta$ of Pro2), 2.46-2.57 (m, $2 \mathrm{H}, \mathrm{H} \alpha$ of biotin), $2.65(\mathrm{~d}, 1 \mathrm{H}, J=13.0 \mathrm{~Hz}$, $\left.\mathrm{H}^{4}\right)$, 2.73-2.93 $\left(\mathrm{m}, 3 \mathrm{H}, \mathrm{H} \beta\right.$ of Asp, $\left.\mathrm{H}^{4}\right)$, 3.03-3.15 $(\mathrm{m}, 2 \mathrm{H}, \mathrm{H} \delta$ of Arg), 3.16-3.25 (m, 2H, $\left.\mathrm{H}^{1}\right), 3.47-3.74(\mathrm{~m}, 4 \mathrm{H}, \mathrm{H} \delta$ of Pro1, $\mathrm{H} \delta$ of Pro2), 4.05-4.14 (m, $2 \mathrm{H}, \mathrm{CH}_{2}$ of $1, \mathrm{H} \beta$ of Thr), 4.17-4.37 (m, $4 \mathrm{H}$, $\mathrm{H} \alpha$ of Pro1, $\mathrm{H} \alpha$ of Pro2, $\mathrm{H} \alpha$ of Thr, $\left.\mathrm{H}^{2}\right), 4.46-4.65\left(\mathrm{~m}, 5 \mathrm{H}, \mathrm{CH}_{2}\right.$ of 1, $\mathrm{H} \alpha$ of Ala, $\mathrm{H} \alpha$ of $\mathrm{Arg}, \mathrm{H} \alpha$ of Asp, $\left.\mathrm{H}^{3}\right) .{ }^{13} \mathrm{C} \mathrm{NMR}\left(75 \mathrm{MHz}, \mathrm{D}_{2} \mathrm{O}\right) \delta$ (ppm): $15.2\left(\mathrm{CH}_{3}\right.$ of Ala), $18.8\left(\mathrm{CH}_{3}\right.$ of Thr), $22.3\left(\mathrm{CH}_{3}\right.$ of 1$), 24.0$ ( $C \gamma$ of Arg), 24.6 ( $C \gamma$ of Pro1, $C \gamma$ of Pro2), 27.4 ( $C \beta$ of Arg), 27.5 (C $\delta$ of biotin), 27.6 ( $C \beta$ of biotin), 27.8 ( $C \gamma$ of biotin), 29.2 ( $C \beta$ of Pro1), 29.5 (C $\beta$ of Pro2), 34.3 ( $C \alpha$ of biotin), 34.8 (C $\beta$ of Asp),

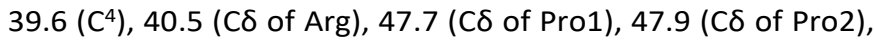
48.3 (C $\alpha$ of Ala), 50.1 (C $\alpha$ of Asp), 51.1 (C $\alpha$ of Arg), $52.3\left(\mathrm{CH}_{2}\right.$ of 1), $55.2\left(\mathrm{C}^{1}\right), 59.1$ ( $\mathrm{C} \alpha$ of Thr), 60.2 ( $\mathrm{C} \alpha$ of Pro2), 60.7 ( $\mathrm{C} \alpha$ of Pro1), 60.8 (C $\alpha$ of biotin), $62.0\left(C^{2}\right), 67.0$ (C $\beta$ of Thr), 86.3 ( $C \alpha$ of 1 ), $156.6(\mathrm{HN}=\mathrm{C}$ of $\mathrm{Arg}), 165.2,169.1,171.3,171.4,172.1,172.4$, 172.6, 173.9, 174.0, 176.7, 178.8 (CO).

Peptide 12 (Fmoc-Ala-1-Ala-His-Asn-Cys-Gly-NH $\mathrm{NH}_{2}$ was synthesized and purified (method C) following the general protocol described above in a $40 \%$ global yield. Semipreparative HPLC retention time: $25.39 \mathrm{~min}$. $\mathrm{HRMS}(\mathrm{ESI}) \mathrm{m} / \mathrm{z}=$ 956.3012, calculated for $\mathrm{C}_{40} \mathrm{H}_{50} \mathrm{~N}_{11} \mathrm{O}_{13} \mathrm{~S}_{2}[\mathrm{M}+\mathrm{H}]^{+}=956.3025 .{ }^{1} \mathrm{H}$ NMR (300 MHz, CD ${ }_{3} \mathrm{CN} / \mathrm{D}_{2} \mathrm{O}$ (95:5)) $\delta(\mathrm{ppm}):$ 1.18-1.47 (m, 6H, $\mathrm{CH}_{3}$ of Fmoc-Ala, $\mathrm{CH}_{3}$ of Ala), $1.79\left(\mathrm{~s}, 3 \mathrm{H}, \mathrm{CH}_{3}\right.$ of 1$)$, 2.71-2.74 (m, $2 \mathrm{H}, \mathrm{H} \beta$ of $\mathrm{His}$ ), 2.86-2.98 (m, $2 \mathrm{H}, \mathrm{H \beta}$ of $\mathrm{Cys}$ ), 3.01-3.28 (m, $2 \mathrm{H}$, $\mathrm{H} \beta$ of Asn), 3.66-3.89 (m, 2H, Ha of Gly), $4.15(\mathrm{~d}, 1 \mathrm{H}, J=10.4 \mathrm{~Hz}$, $\mathrm{CH}_{2}$ of 1), 4.20-4.53 (m, 6H, $\mathrm{H} \alpha$ of $\mathrm{Cys}, \mathrm{CH}_{2}$ of $\mathrm{Fmoc}, \mathrm{CH}$ of Fmoc, $\mathrm{H} \alpha$ of Fmoc-Ala, $\mathrm{H} \alpha$ of Ala), 4.54-4.68 (m, 2H, H $\alpha$ of His, $\mathrm{H} \alpha$ of Asn), $4.74\left(\mathrm{~d}, 1 \mathrm{H}, J=10.4 \mathrm{~Hz}, \mathrm{CH}_{2}\right.$ of 1), 7.21 (s, 1H, Hס of His), 7.32-7.52 (m, $4 \mathrm{H}$, Arom.), 7.60-7.71 (m, 2H, Arom.), 7.79-7.90 (m, $2 \mathrm{H}$, Arom.) 8.43 (s, $1 \mathrm{H}, \mathrm{H} \varepsilon$ of His). ${ }^{13} \mathrm{C} \mathrm{NMR} \mathrm{(75} \mathrm{MHz,}$ $\left.\mathrm{CD}_{3} \mathrm{CN} / \mathrm{D}_{2} \mathrm{O}(95: 5)\right) \delta(\mathrm{ppm}): 15.8,16.6\left(\mathrm{CH}_{3}\right.$ of Fmoc-Ala, $\mathrm{CH}_{3}$ Ala), 22.5 ( $\mathrm{CH}_{3}$ of 1), 25.3 ( $\mathrm{C} \beta$ of $\mathrm{Cys}$ ), 26.2 ( $\mathrm{C} \beta$ of $\mathrm{Asn}$ ), 35.9 ( $\mathrm{C} \beta$ of His), 42.1 ( $\mathrm{C} \alpha$ of Gly), 46.9 ( $\mathrm{CH}$ of Fmoc), 49.8 ( $\mathrm{C} \alpha$ of FmocAla, $\mathrm{C} \alpha$ of Ala), 50.6 ( $\mathrm{C} \alpha$ of His), 52.2 ( $\mathrm{CH}_{2}$ of 1), 52.5 ( $\mathrm{C} \alpha$ of Asn), 56.0 (C $\alpha$ of $\mathrm{Cys}$ ), 66.9 ( $\mathrm{CH}_{2}$ of Fmoc), 85.9 (C $\alpha$ of 1), 120.0, 125.3,
127.2, 127.8, 128.9, 133.5, 141.1, 143.9, 144.0 (Arom), 156.3 (CO of Fmoc), 168.1, 170.4, 170.8, 171.7, 172.5, 173.0 (CO).

Peptide 13 (Fmoc-Ala-1-Ala-His-Asn-Ser-Gly- $\mathrm{NH}_{2}$ ) was synthesized and purified (method C) following the general protocol described above in a $30 \%$ global yield. Semipreparative HPLC retention time: $24.14 \mathrm{~min}$. HRMS (ESI) $\mathrm{m} / \mathrm{z}=$ 940.3217, calculated for $\mathrm{C}_{40} \mathrm{H}_{50} \mathrm{~N}_{11} \mathrm{O}_{14} \mathrm{~S}[\mathrm{M}+\mathrm{H}]^{+}=940.3254 .{ }^{1} \mathrm{H}$ NMR (300 MHz, CD $\left.{ }_{3} \mathrm{CN} / \mathrm{D}_{2} \mathrm{O}(95: 5)\right) \delta(\mathrm{ppm}): 1.29-1.40(\mathrm{~m}, 6 \mathrm{H}$, $\mathrm{CH}_{3}$ of Fmoc-Ala, $\mathrm{CH}_{3}$ of Ala), 1.79 (s, 3H, $\mathrm{CH}_{3}$ of 1 ), 2.66-2.78 (m, $2 \mathrm{H}, \mathrm{H} \beta$ of $\mathrm{His}), 3.02-3.26(\mathrm{~m}, 2 \mathrm{H}, \mathrm{H} \beta$ of $A s n), 3.71-3.93(\mathrm{~m}, 4 \mathrm{H}$, $\mathrm{H} \alpha$ of Gly, $\mathrm{H} \beta$ of Ser), 4.14 (d, $1 \mathrm{H}, J=10.4 \mathrm{~Hz}, \mathrm{CH}_{2}$ of 1), 4.21$4.54\left(\mathrm{~m}, 6 \mathrm{H}, \mathrm{H} \alpha\right.$ of Ser, $\mathrm{CH}_{2}$ of Fmoc, $\mathrm{CH}$ of Fmoc, $\mathrm{H} \alpha$ of FmocAla, $\mathrm{H} \alpha$ of Ala), 4.57-4.67 (m, 2H, H $\alpha$ of His, $\mathrm{H} \alpha$ of Asn), 4.72 (d, $1 \mathrm{H}, J=10.4 \mathrm{~Hz}, \mathrm{CH}_{2}$ of 1), 7.21 (s, $1 \mathrm{H}, \mathrm{H} \delta$ of His), 7.31-7.46 (m, $4 \mathrm{H}$, Arom), $7.62-7.70(\mathrm{~m}, 2 \mathrm{H}$, Arom) , 7.82-7.88 (m, 2H, Arom), $8.44(\mathrm{~s}, 1 \mathrm{H}, \mathrm{H} \varepsilon$ of $\mathrm{His}) .{ }^{13} \mathrm{C} \mathrm{NMR}\left(75 \mathrm{MHz}, \mathrm{CD}_{3} \mathrm{CN} / \mathrm{D}_{2} \mathrm{O}(95: 5)\right) \delta$ (ppm): 15.8, $16.6\left(\mathrm{CH}_{3}\right.$ of Fmoc-Ala, $\left.\mathrm{CH}_{3} \mathrm{Ala}\right), 22.5\left(\mathrm{CH}_{3}\right.$ of 1$)$, 26.2 ( $C \beta$ of $A s n$ ), 36.1 ( $C \beta$ of His), 42.0 ( $C \alpha$ of $\mathrm{Gly}$ ), 46.9 ( $\mathrm{CH}$ of Fmoc), 49.7 ( $\mathrm{C} \alpha$ of Fmoc-Ala, $\mathrm{C} \alpha$ of Ala), 50.4 ( $\mathrm{C} \alpha$ of His), 52.2 ( $\mathrm{CH}_{2}$ of 1), 52.4 ( $\mathrm{C} \alpha$ of Asn), 55.9 ( $\mathrm{C} \alpha$ of Ser), 61.3 (C $\beta$ of Ser), $66.9\left(\mathrm{CH}_{2}\right.$ of Fmoc), 85.9 ( $\mathrm{C} \alpha$ of 1 ), 120.0, 125.3, 127.2, 127.8, 128.7, 133.5, 141.1, 143.9, 144.0, (Arom), 156.4 (CO of Fmoc), $168.2,170.4,170.8,171.0,171.8,172.5,172.6$ (CO).

Peptide 14 (Fmoc-Ala-1-Ala-His-Asn-Thr-Gly- $\mathrm{NH}_{2}$ ) was synthesized and purified (method $\mathrm{C}$ ) following the general protocol described above in a $40 \%$ global yield. Semipreparative HPLC retention time: $23.70 \mathrm{~min}$. HRMS (ESI) $\mathrm{m} / \mathrm{z}=$ 954.3418, calculated for $\mathrm{C}_{41} \mathrm{H}_{52} \mathrm{~N}_{11} \mathrm{O}_{14} \mathrm{~S}[\mathrm{M}+\mathrm{H}]^{+}=954.3410 .{ }^{1} \mathrm{H}$ NMR (300 MHz, CD $\left.{ }_{3} \mathrm{CN} / \mathrm{D}_{2} \mathrm{O}(95: 5)\right) \delta(\mathrm{ppm}): 1.13(\mathrm{~d}, 3 \mathrm{H}, J=6.6$ $\mathrm{Hz}, \mathrm{CH}_{3}$ of Thr), 1.29-1.41 (m, 6H, $\mathrm{CH}_{3}$ of Fmoc-Ala, $\mathrm{CH}_{3}$ of Ala), $1.79\left(\mathrm{~s}, 3 \mathrm{H}, \mathrm{CH}_{3}\right.$ of 1$), 2.68-2.79(\mathrm{~m}, 2 \mathrm{H}, \mathrm{H} \beta$ of His), 3.02-3.30 (m, $2 \mathrm{H}, \mathrm{H} \beta$ of Asn), 3.69-3.93 (m, $2 \mathrm{H}, \mathrm{H} \alpha$ of Gly), 4.15 (d, $1 \mathrm{H}, J=10.3$ $\mathrm{Hz}, \mathrm{CH}_{2}$ of 1), 4.21-4.55 (m, 7H, $\mathrm{H} \beta$ of Thr, $\mathrm{H} \alpha$ of $\mathrm{Thr}, \mathrm{CH}_{2}$ of Fmoc, $\mathrm{CH}$ of Fmoc, $\mathrm{H} \alpha$ of Fmoc-Ala, $\mathrm{H} \alpha$ of Ala), 4.61-4.79 (m, 3H, $\mathrm{H} \alpha$ of $\mathrm{His}, \mathrm{H} \alpha$ of Asn, $\mathrm{CH}_{2}$ of 1), 7.22 (s, $1 \mathrm{H}, \mathrm{H} \delta$ of $\mathrm{His}$ ), 7.28-7.49 (m, 4H, Arom), 7.61-7.72 (m, 2H, Arom), 7.78-7.89 (m, $2 \mathrm{H}$, Arom), 8.46 (s, $1 \mathrm{H}, \mathrm{H} \varepsilon$ of $\mathrm{His}) .{ }^{13} \mathrm{C} \mathrm{NMR}\left(75 \mathrm{MHz}, \mathrm{CD}_{3} \mathrm{CN} / \mathrm{D}_{2} \mathrm{O}\right.$ (95:5)) $\delta$ (ppm): 15.9, $16.6\left(\mathrm{CH}_{3}\right.$ of Fmoc-Ala, $\mathrm{CH}_{3}$ of Ala), 18.9 ( $\mathrm{CH}_{3}$ of Thr), 22.5 ( $\mathrm{CH}_{3}$ of 1), 26.3 ( $\mathrm{C} \beta$ of $\left.A s n\right), 36.1$ ( $\mathrm{C} \beta$ of His), 42.1 ( $\mathrm{C} \alpha$ of Gly), 46.9 ( $\mathrm{CH}$ of Fmoc), 49.7, 49.8 (C $\alpha$ of Fmoc-Ala, $\mathrm{C} \alpha$ of Ala), 50.6 ( $\mathrm{C} \alpha$ of His), $52.2\left(\mathrm{CH}_{2}\right.$ of 1), 52.5 (C $\alpha$ of Asn), 59.1 ( $\mathrm{C} \alpha$ of Thr), 66.8 ( $\mathrm{CH}_{2}$ of Fmoc, $\mathrm{C} \beta$ of Thr), 85.9 ( $\mathrm{C} \alpha$ of 1 ), 120.0, 125.3, 127.2, 127.8, 128.8, 133.6, 141.1, 143.9, 144.0, (Arom), 156.3 (CO of Fmoc), 168.1, 170.5, 170.8, 171.3, 171.9, 172.6, $173.2(\mathrm{CO})$.

Peptide 15 (Fmoc-Ala-1-Ala-His-Asn-Lys-Gly- $\mathrm{NH}_{2}$ ) was synthesized and purified (method $\mathrm{C}$ ) following the general protocol described above in a $49 \%$ global yield. Semipreparative HPLC retention time: $20.67 \mathrm{~min}$. HRMS (ESI) $\mathrm{m} / \mathrm{z}=$ 981.3849, calculated for $\mathrm{C}_{43} \mathrm{H}_{57} \mathrm{~N}_{12} \mathrm{O}_{13} \mathrm{~S}[\mathrm{M}+\mathrm{H}]^{+}=981.3883 .{ }^{1} \mathrm{H}$ NMR (300 MHz, CD $\left.{ }_{3} \mathrm{CN} / \mathrm{D}_{2} \mathrm{O}(95: 5)\right) \delta(\mathrm{ppm}): 1.25-1.48(\mathrm{~m}, 8 \mathrm{H}$, $\mathrm{CH}_{3}$ of Fmoc-Ala, $\mathrm{CH}_{3}$ of Ala, $\mathrm{H} \gamma$ of Lys), 1.52-1.91 (m, 7H, $\mathrm{CH}_{3}$ of 1, $\mathrm{H} \delta$ of Lys, $\mathrm{H} \beta$ of Lys), 2.65-2.76 (m, $2 \mathrm{H}, \mathrm{H} \beta$ of His), 2.86-2.94 (m, $2 \mathrm{H}, \mathrm{H} \varepsilon$ of Lys), 3.07-3.30 (m, $2 \mathrm{H}, \mathrm{H} \beta$ of Asn), 3.70-3.88 (m, $2 \mathrm{H}, \mathrm{H} \alpha$ of Gly), 4.15 (d, $1 \mathrm{H}, J=10.4 \mathrm{~Hz}, \mathrm{CH}_{2}$ of 1), 4.18-4.53 (m, $6 \mathrm{H}, \mathrm{H} \alpha$ of Lys, $\mathrm{CH}_{2}$ of Fmoc, $\mathrm{H} \alpha$ of Fmoc-Ala, $\mathrm{H} \alpha$ of Ala), 4.56- 
$4.67\left(\mathrm{~m}, 2 \mathrm{H}, \mathrm{H} \alpha\right.$ of His, $\mathrm{H} \alpha$ of Asn), 4.72 (d, $1 \mathrm{H}, J=10.4 \mathrm{~Hz}, \mathrm{CH}_{2}$ of 1), $7.23(\mathrm{~s}, 1 \mathrm{H}, \mathrm{H} \delta$ of $\mathrm{His}), 7.29-7.50(\mathrm{~m}, 4 \mathrm{H}$, Arom), 7.62-7.71 (m, 2H, Arom), 7.78-7.89 (m, 2H, Arom), 8.48 (s, 1H, He of His). ${ }^{13} \mathrm{C}$ NMR $\left(75 \mathrm{MHz}, \mathrm{CD}_{3} \mathrm{CN} / \mathrm{D}_{2} \mathrm{O}(95: 5)\right) \delta(\mathrm{ppm}): 15.8,16.6\left(\mathrm{CH}_{3}\right.$ of Fmoc-Ala, $\mathrm{CH}_{3}$ Ala), 21.9 (C $\gamma$ of Lys), $22.5\left(\mathrm{CH}_{3}\right.$ of 1 ), 26.0 (C $\beta$ of Asn, $C \delta$ of Lys), 30.0 (C $\beta$ of Lys), 35.9 (C $\beta$ of His), 39.2 (CE of Lys), 42.0 (C $\alpha$ of Gly), 46.9 (CH of Fmoc), 49.8 (C $\alpha$ of Fmoc-Ala, $\mathrm{C} \alpha$ of Ala), 50.5 ( $\mathrm{C} \alpha$ of His), $52.2\left(\mathrm{CH}_{2}\right.$ of 1), 52.6 ( $\mathrm{C} \alpha$ of Asn), 53.3 ( $\mathrm{C} \alpha$ of Lys), 66.9 ( $\mathrm{CH}_{2}$ of Fmoc), 86.0 (C $\alpha$ of 1), 120.0, 125.3, 127.2, 127.8, 128.9, 133.5, 141.1, 143.9, (Arom), 156.4 (CO of Fmoc), 168.2, 170.7, 170.9, 171.9, 172.6, 172.7, 172.9, 173.4 (CO).

Peptide 16 (Fmoc-Ala-1-Ala-His-Cys-Asn-Gly- $\mathrm{NH}_{2}$ ) was synthesized and purified (method $\mathrm{C}$ ) following the general protocol described above in a $30 \%$ global yield. Semipreparative HPLC retention time: $26.00 \mathrm{~min}$. HRMS (ESI) $\mathrm{m} / \mathrm{z}=$ 956.3029, calculated for $\mathrm{C}_{40} \mathrm{H}_{50} \mathrm{~N}_{11} \mathrm{O}_{13} \mathrm{~S}_{2}(\mathrm{MH}+)=956.3025 .{ }^{1} \mathrm{H}$ NMR (300 MHz, CD $\left.{ }_{3} \mathrm{CN} / \mathrm{D}_{2} \mathrm{O}(95: 5)\right) \delta(\mathrm{ppm}):$ 1.29-1.40 (m, $6 \mathrm{H}$, $\mathrm{CH}_{3}$ of Fmoc-Ala, $\mathrm{CH}_{3}$ of Ala), 1.79 (s, 3H, $\mathrm{CH}_{3}$ of 1), 2.73-2.76 (m, $2 \mathrm{H}, \mathrm{H} \beta$ of $\mathrm{His}$ ), 2.83-2.89 (m, $2 \mathrm{H}, \mathrm{H} \beta$ of Cys), 3.03-3.30 (m, $2 \mathrm{H}$, $\mathrm{H} \beta$ of Asn), 3.69-3.90 (m, $2 \mathrm{H}, \mathrm{H} \alpha$ of Gly), $4.14(\mathrm{~d}, 1 \mathrm{H}, J=10.4 \mathrm{~Hz}$, $\mathrm{CH}_{2}$ of 1), 4.20-4.54 (m, 6H, Ha of Cys, $\mathrm{CH}_{2}$ of Fmoc, $\mathrm{CH}$ of Fmoc, $\mathrm{H} \alpha$ of Fmoc-Ala, $\mathrm{H} \alpha$ of Ala), 4.62-4.75 (m, 3H, $\mathrm{H} \alpha$ of His, $\mathrm{H} \alpha$ of Asn, $\mathrm{CH}_{2}$ of 1), 7.23 (s, $1 \mathrm{H}, \mathrm{H} \delta$ of His), 7.30-7.46 (m, $4 \mathrm{H}$, Arom), 7.57-7.70 (m, 2H, Arom), 7.78-7.89 (m, 2H, Arom), 8.47 (s, $1 \mathrm{H}$, $\mathrm{H} \varepsilon$ of $\mathrm{His}) .{ }^{13} \mathrm{C} N M R\left(75 \mathrm{MHz}, \mathrm{CD}_{3} \mathrm{CN} / \mathrm{D}_{2} \mathrm{O}(95: 5)\right) \delta$ (ppm): 15.9, 16.7 ( $\mathrm{CH}_{3}$ of Fmoc-Ala, $\mathrm{CH}_{3}$ Ala), 22.5 ( $\mathrm{CH}_{3}$ of 1 ), 25.2 ( $\mathrm{C} \beta$ of $\mathrm{Cys}$ ), 26.5 ( $C \beta$ of Asn), 36.1 ( $C \beta$ of His), 42.2 ( $\mathrm{C} \alpha$ of $\mathrm{Gly}$ ), 46.9 ( $\mathrm{CH}$ of Fmoc), $49.8\left(\mathrm{CH}_{3}\right.$ of Fmoc-Ala, $\mathrm{CH}_{3} \mathrm{Ala}$ ), 50.3 ( $\mathrm{C} \alpha$ of His), 52.3 ( $\mathrm{CH}_{2}$ of $1, \mathrm{C} \alpha$ of Asn), 56.0 ( $\mathrm{C} \alpha$ of $\mathrm{Cys}$ ), $66.8\left(\mathrm{CH}_{2}\right.$ of $\left.\mathrm{Fmoc}\right), 86.0$ (C $\alpha$ of 1), 120.0, 125.3, 127.2, 127.8, 129.0, 133.6, 141.1, 143.9, 144.0 (Arom), 156.2 (CO of Fmoc), 168.1, 168.3, 170.5, 170.8, $171.3,172.3,173.5$ (CO).

Peptide 17 (Fmoc-Ala-1-Ala-His-Asn-Gly-Cys- $\mathrm{NH}_{2}$ ) was synthesized and purified (method $\mathrm{C}$ ) following the general protocol described above in a $31 \%$ global yield. Semipreparative HPLC retention time: $26.14 \mathrm{~min}$. $\mathrm{HRMS}(\mathrm{ESI}) \mathrm{m} / \mathrm{z}=$ 956.3006, calculated for $\mathrm{C}_{40} \mathrm{H}_{50} \mathrm{~N}_{11} \mathrm{O}_{13} \mathrm{~S}_{2}[\mathrm{M}+\mathrm{H}]^{+}=956.3025 .{ }^{1} \mathrm{H}$ NMR (300 MHz, CD ${ }_{3} \mathrm{CN} / \mathrm{D}_{2} \mathrm{O}$ (95:5)) $\delta(\mathrm{ppm}):$ 1.20-1.40 (m, $6 \mathrm{H}$, $\mathrm{CH}_{3}$ of Fmoc-Ala, $\mathrm{CH}_{3}$ of Ala), 1.79 (s, 3H, $\mathrm{CH}_{3}$ of 1 ), 2.80-2.93 (m, $4 \mathrm{H}, \mathrm{H} \beta$ of $\mathrm{His}, \mathrm{H} \beta$ of $\mathrm{Cys}$ ), 3.00-3.27 (m, $2 \mathrm{H}, \mathrm{H \beta}$ of Asn), 3.69-3.99 (m, $2 \mathrm{H}, \mathrm{H} \alpha$ of Gly), 4.15 (d, $1 \mathrm{H}, J=10.4 \mathrm{~Hz}, \mathrm{CH}_{2}$ of 1 ), 4.19-4.52 (m, $6 \mathrm{H}, \mathrm{H} \beta$ of Cys, $\mathrm{CH}_{2}$ of Fmoc, $\mathrm{CH}$ of Fmoc, Fmoc-Ala, $\mathrm{H} \alpha$ of Ala), 4.53-4.65 (m, 2H, H $\alpha$ of His, $\mathrm{H} \alpha$ of Asn), 4.73 (d, $1 \mathrm{H}, J=10.4$ $\mathrm{Hz}, \mathrm{CH}_{2}$ of 1), 7.20 (s, $1 \mathrm{H}, \mathrm{H} \delta$ of His), 7.31-7.50 (m, $4 \mathrm{H}$, Arom), 7.62-7.74 (m, 2H, Arom), 7.81-7.85 (m, 2H, Arom), 8.42 (s, $1 \mathrm{H}$, $\mathrm{H} \varepsilon$ of $\mathrm{His}) .{ }^{13} \mathrm{C} N M R\left(75 \mathrm{MHz}, \mathrm{CD}_{3} \mathrm{CN} / \mathrm{D}_{2} \mathrm{O}\right.$ (95:5)) $\delta$ (ppm): 15.8 , $16.6\left(\mathrm{CH}_{3}\right.$ of Fmoc-Ala, $\mathrm{CH}_{3}$ of Ala), $22.5\left(\mathrm{CH}_{3}\right.$ of 1$), 25.5$ ( $\mathrm{C} \beta$ of Cys), 26.1 ( $C \beta$ of Asn), 35.9 ( $C \beta$ of His), 42.8 ( $\mathrm{C} \alpha$ of $\mathrm{Gly}$ ), 46.9 ( $\mathrm{CH}$ of Fmoc), 49.8 ( $\mathrm{CH}_{3}$ of Fmoc-Ala, $\mathrm{CH}_{3} \mathrm{Ala}$ ), 50.3 ( $\mathrm{C} \alpha$ of His), 52.2 ( $\mathrm{CH}_{2}$ of $1, \mathrm{C} \alpha$ of Asn), 55.5 ( $\mathrm{C} \alpha$ of $\mathrm{Cys}$ ), $66.9\left(\mathrm{CH}_{2}\right.$ of $\mathrm{Fmoc}$ ), 85.9 (C $\alpha$ of 1), 120.0, 125.3, 127.2, 127.8, 128.9, 133.5, 141.1, 143.9 (Arom), 156.4 (CO of Fmoc), 168.2, 170.0, 170.5, 170.8, 172.1, $172.6,172.9,173.3$ (CO).

Peptide 18 (Fmoc-Ala-1-His-Asn-Cys-Gly- $\mathrm{NH}_{2}$ ) was synthesized and purified (method C) following the general protocol described above in a $35 \%$ global yield. Semi-preparative HPLC retention time: $25.83 \mathrm{~min}$. HRMS (ESI) $\mathrm{m} / \mathrm{z}=885.2623$, calculated for $\mathrm{C}_{37} \mathrm{H}_{45} \mathrm{~N}_{10} \mathrm{O}_{12} \mathrm{~S}_{2}[\mathrm{M}+\mathrm{H}]^{+}=885.2654 .{ }^{1} \mathrm{H}$ NMR (300 $\left.\mathrm{MHz}, \mathrm{CD}_{3} \mathrm{CN} / \mathrm{D}_{2} \mathrm{O}(95: 5)\right) \delta(\mathrm{ppm}): 1.36\left(\mathrm{~d}, 3 \mathrm{H}, J=7.0 \mathrm{~Hz}, \mathrm{CH}_{3}\right.$ of Ala), $1.69\left(\mathrm{~s}, 3 \mathrm{H}, \mathrm{CH}_{3}\right.$ of 1), 2.71-2.75 (m, $2 \mathrm{H}, \mathrm{H} \beta$ of His), 2.87$2.94(\mathrm{~m}, 2 \mathrm{H}, \mathrm{H} \beta$ of $\mathrm{Cys}), 3.11-3.43$ ( $m, 2 \mathrm{H}, \mathrm{H} \beta$ of Asn), 3.66-3.91 (m, $2 \mathrm{H}, \mathrm{H} \alpha$ of Gly), 4.10 (d, $1 \mathrm{H}, J=10.4 \mathrm{~Hz}, \mathrm{CH}_{2}$ of 1), 4.21-4.49 (m, $5 \mathrm{H}, \mathrm{H} \alpha$ of $\mathrm{Cys}, \mathrm{CH}_{2}$ of Fmoc, $\mathrm{CH}$ of Fmoc, $\mathrm{H} \alpha$ of Ala), 4.61$4.80\left(\mathrm{~m}, 3 \mathrm{H}, \mathrm{H} \alpha\right.$ of His, $\mathrm{H} \alpha$ of Asn, $\mathrm{CH}_{2}$ of 1$), 7.24(\mathrm{~s}, 1 \mathrm{H}, \mathrm{H} \delta$ of $\mathrm{His})$, 7.29-7.53 (m, 4H, Arom), 7.60-7.69 (m, 2H, Arom), 7.79$7.90(\mathrm{~m}, 2 \mathrm{H}, \mathrm{Arom}), 8.48$ (s, $1 \mathrm{H}, \mathrm{H} \varepsilon$ of $\mathrm{His}) .{ }^{13} \mathrm{C} \mathrm{NMR}(75 \mathrm{MHz}$, $\left.\mathrm{CD}_{3} \mathrm{CN} / \mathrm{D}_{2} \mathrm{O}(95: 5)\right) \delta$ (ppm): $15.9\left(\mathrm{CH}_{3}\right.$ of Ala), $22.5\left(\mathrm{CH}_{3}\right.$ of $\left.\mathbf{1}\right)$, 25.2 (C $\beta$ of $C y s$ ), 26.1 (C $\beta$ of $A s n$ ), 35.9 (C $\beta$ of His), 42.1 ( $C \alpha$ of Gly), 46.9 ( $\mathrm{CH}$ of $\mathrm{Fmoc}$ ), 49.7 ( $\mathrm{C} \alpha$ of Ala), 50.8 ( $\mathrm{C} \alpha$ of His), 52.2 ( $\mathrm{CH}_{2}$ of 1), 52.5 ( $\mathrm{C} \alpha$ of Asn), 55.9 ( $\mathrm{C} \alpha$ of $\left.\mathrm{Cys}\right), 66.8$ ( $\mathrm{CH}_{2}$ of Fmoc), 85.9 (C $\alpha$ of 1), 120.0, 125.3, 127.2, 127.8, 129.1, 133.7, 141.1, 143.9, 144.0, (Arom), 156.2 (CO of Fmoc), 168.4, 169.8, 170.2, 170.4, 170.6, 171.7, 172.2, 173.0 (CO).

General protocol for the transacylation reaction. Peptides 12-25 were dissolved in a 24:1 mixture of $C D_{3} C N / D_{2} O$ in an NMR tube. A slight excess of triethylamine (1.5-2.0 equiv.) was then added and a ${ }^{1} \mathrm{H}$ NMR spectrum was immediately acquired. When needed, further spectra were recorded at different times. Conversion values were derived from the ${ }^{1} \mathrm{H}$ NMR spectra of reaction mixtures.

Peptide 19 (1-Ala-His-Asn-Cys(Fmoc-Ala-S)-Gly- $\mathrm{NH}_{2}$ ) was quantitatively obtained after treatment of peptide $12(4 \mathrm{mg}$, $0.004 \mathrm{mmol})$ with TEA $(1.0 \mu \mathrm{L}, 0.007 \mathrm{mmol})$ in a $24: 1$ mixture of $\mathrm{CD}_{3} \mathrm{CN} / \mathrm{D}_{2} \mathrm{O}$ at room temperature for $5 \mathrm{~min}$. $\mathrm{MS}(\mathrm{ESI}) \mathrm{m} / \mathrm{z}=$ 956.3, calculated for $\mathrm{C}_{40} \mathrm{H}_{50} \mathrm{~N}_{11} \mathrm{O}_{13} \mathrm{~S}_{2}[\mathrm{M}+\mathrm{H}]^{+}=956.3025 .{ }^{1} \mathrm{H}$ NMR (300 MHz, CD $\left.{ }_{3} \mathrm{CN} / \mathrm{D}_{2} \mathrm{O}(95: 5)\right) \delta(\mathrm{ppm}): 1.25-1.35\left(\mathrm{~m}, 6 \mathrm{H}, \mathrm{CH}_{3}\right.$ of Fmoc-Ala, $\mathrm{CH}_{3}$ of Ala), $1.62\left(\mathrm{~s}, 3 \mathrm{H}, \mathrm{CH}_{3}\right.$ of 1$), 2.50-2.60(\mathrm{~m}, 4 \mathrm{H}$, $\mathrm{H} \beta$ of His, $H \beta$ of $C y s), 3.17-3.30$ (m, $1 \mathrm{H}, \mathrm{H} \beta$ of Asn), 3.35-3.48 (m, $2 \mathrm{H}, \mathrm{H} \beta$ of Asn, $\mathrm{CH}_{2}$ of 1), 3.62 (d, $1 \mathrm{H}, J=17.0 \mathrm{~Hz}, \mathrm{H \alpha}$ of Gly), 3.81 (d, $1 \mathrm{H}, J=17.0 \mathrm{~Hz}, \mathrm{H} \alpha$ of Gly), $4.04\left(\mathrm{~d}, 1 \mathrm{H}, J=12.7 \mathrm{~Hz}, \mathrm{CH}_{2}\right.$ of 1 ), 4.19-4.44 (m, 7H, $\mathrm{H} \alpha$ of $\mathrm{Cys}, \mathrm{CH}_{2}$ of $\mathrm{Fmoc}, \mathrm{CH}$ of $\mathrm{Fmoc}, \mathrm{H} \alpha$ of Fmoc-Ala, $\mathrm{H} \alpha$ of Ala, $\mathrm{H} \alpha$ of Asn), 4.49-4.56 (m, $1 \mathrm{H}, \mathrm{H} \alpha$ of His), $6.84(\mathrm{~s}, 1 \mathrm{H}, \mathrm{H} \delta$ of His), 7.29-7.46 (m, 4H, Arom.), 7.53 (s, 1H, Hع of His), 7.62-7.72 (m, 2H, Arom.), 7.77-7.87 (m, 2H, Arom.).

Peptide 20 (1-Ala-His-Cys(Fmoc-Ala-S)-Asn-Gly- $\mathrm{NH}_{2}$ ) was quantitatively obtained after treatment of peptide $16(5 \mathrm{mg}$, $0.005 \mathrm{mmol})$ with TEA $(1.0 \mu \mathrm{L}, 0.007 \mathrm{mmol})$ in a $24: 1$ mixture of $\mathrm{CD}_{3} \mathrm{CN} / \mathrm{D}_{2} \mathrm{O}$ at room temperature for $5 \mathrm{~min}$. $\mathrm{MS}(\mathrm{ESI}) \mathrm{m} / \mathrm{z}=$ 956.3, calculated for $\mathrm{C}_{40} \mathrm{H}_{50} \mathrm{~N}_{11} \mathrm{O}_{13} \mathrm{~S}_{2}[\mathrm{M}+\mathrm{H}]^{+}=956.3025 .{ }^{1} \mathrm{H} \mathrm{NMR}$ (300 MHz, CD $\left.{ }_{3} \mathrm{CN} / \mathrm{D}_{2} \mathrm{O}(95: 5)\right) \delta(\mathrm{ppm}): 1.24-1.39\left(\mathrm{~m}, 6 \mathrm{H}, \mathrm{CH}_{3}\right.$ of Fmoc-Ala, $\mathrm{CH}_{3}$ of Ala), 1.61 (s, 3H, $\mathrm{CH}_{3}$ of 1$), 2.60-2.81(\mathrm{~m}, 4 \mathrm{H}$, $\mathrm{H} \beta$ of $\mathrm{His}, \mathrm{H \beta}$ of Cys), 3.08-3.34 (m, $2 \mathrm{H}, \mathrm{H \beta}$ of Asn) $3.43(\mathrm{~d}, 1 \mathrm{H}, J$ $=12.7 \mathrm{~Hz}, \mathrm{CH}_{2}$ of 1), 3.68 (d, $1 \mathrm{H}, J=17.1 \mathrm{~Hz}, \mathrm{H} \alpha$ of Gly), 3.85 (d, $1 \mathrm{H}, J=17.1 \mathrm{~Hz}, \mathrm{H} \alpha$ of Gly), $4.01\left(\mathrm{~d}, 1 \mathrm{H}, J=12.7 \mathrm{~Hz}, \mathrm{CH}_{2}\right.$ of 1 ), 4.19-4.43 (m, 7H, $\mathrm{H} \alpha$ of Cys, $\mathrm{CH}_{2}$ of Fmoc, $\mathrm{CH}$ of Fmoc, $\mathrm{H} \alpha$ of Fmoc-Ala, $\mathrm{H} \alpha$ of Ala, $\mathrm{H} \alpha$ of Asn), 4.53-4.60 (m, $1 \mathrm{H}, \mathrm{H} \alpha$ of His), 6.84 (s, $1 \mathrm{H}, \mathrm{H} \delta$ of His), 7.29-7.44 (m, 4H, Arom.), 7.56 (s, $1 \mathrm{H}, \mathrm{H} \varepsilon$ of His), 7.61-7.70 (m, 2H, Arom.), 7.77-7.87 (m, 2H, Arom.).

Peptide 21 (1-Ala-His-Asn-Gly-Cys(Fmoc-Ala-S)-NH $\mathrm{NH}_{2}$ was obtained ( $70 \%$ conversion) after treatment of peptide 17 ( $4 \mathrm{mg}$, 
$0.004 \mathrm{mmol})$ with TEA $(1.0 \mu \mathrm{L}, 0.007 \mathrm{mmol})$ in a $24: 1$ mixture of $\mathrm{CD}_{3} \mathrm{CN} / \mathrm{D}_{2} \mathrm{O}$ at room temperature for $5 \mathrm{~min}$. MS $(\mathrm{ESI}) \mathrm{m} / \mathrm{z}=$ 956.3, calculated for $\mathrm{C}_{40} \mathrm{H}_{50} \mathrm{~N}_{11} \mathrm{O}_{13} \mathrm{~S}_{2}[\mathrm{M}+\mathrm{H}]^{+}=956.3025 .{ }^{1} \mathrm{H} \mathrm{NMR}$ (300 MHz, CD ${ }_{3} \mathrm{CN} / \mathrm{D}_{2} \mathrm{O}$ (95:5)) $\delta$ (ppm): 1.21-1.37 (m, 6H, $\mathrm{CH}_{3}$ of Fmoc-Ala, $\mathrm{CH}_{3}$ of Ala), 1.57 (s, $3 \mathrm{H}, \mathrm{CH}_{3}$ of 1 ), 2.80-3.18 (m, $5 \mathrm{H}$, $\mathrm{H} \beta$ of $\mathrm{His}, \mathrm{H \beta}$ of Cys, $\mathrm{H \beta}$ of Asn), 3.25-3.49 (m, $2 \mathrm{H}, \mathrm{H} \beta$ of Asn, $\mathrm{CH}_{2}$ of 1$), 3.68(\mathrm{~d}, 1 \mathrm{H}, J=16.9 \mathrm{~Hz}, \mathrm{H} \alpha$ of Gly), $3.85(\mathrm{~d}, 1 \mathrm{H}, J=17.0$ $\mathrm{Hz}, \mathrm{H} \alpha$ of Gly), $3.92\left(\mathrm{~d}, 1 \mathrm{H}, J=12.1 \mathrm{~Hz}, \mathrm{CH}_{2}\right.$ of 1 ), 4.15-4.50 (m, $7 \mathrm{H}, \mathrm{H} \alpha$ of $\mathrm{Cys}, \mathrm{CH}_{2}$ of Fmoc, $\mathrm{CH}$ of Fmoc, $\mathrm{H} \alpha$ of Fmoc-Ala, $\mathrm{H} \alpha$ of

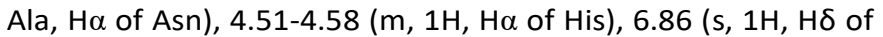
His), 7.28-7.46 (m, 4H, Arom.), 7.53 (s, $1 \mathrm{H}, \mathrm{H} \varepsilon$ of His), 7.62-7.72 ( $\mathrm{m}, 2 \mathrm{H}$, Arom.), 7.77-7.87 (m, 2H, Arom.).

Peptide 22 (1-His-Asn-Cys(Fmoc-Ala-S)-Gly- $\mathrm{NH}_{2}$ ) was quantitatively obtained after treatment of peptide $18(6 \mathrm{mg}$, $0.006 \mathrm{mmol})$ with TEA $(1.0 \mu \mathrm{L}, 0.007 \mathrm{mmol})$ in a $24: 1$ mixture of $\mathrm{CD}_{3} \mathrm{CN} / \mathrm{D}_{2} \mathrm{O}$ at room temperature for $5 \mathrm{~min}$. $\mathrm{MS}(\mathrm{ESI}) \mathrm{m} / \mathrm{z}=$ 885.2, calculated for $\mathrm{C}_{37} \mathrm{H}_{45} \mathrm{~N}_{10} \mathrm{O}_{12} \mathrm{~S}_{2}[\mathrm{M}+\mathrm{H}]^{+}=885.2654 .{ }^{1} \mathrm{H} \mathrm{NMR}$ (300 MHz, CD $\left.{ }_{3} \mathrm{CN} / \mathrm{D}_{2} \mathrm{O}(95: 5)\right) \delta(\mathrm{ppm}): 1.35$ (d, $3 \mathrm{H}, J=7.2 \mathrm{~Hz}$, $\mathrm{CH}_{3}$ of Fmoc-Ala), 1.58 (s, 3H, $\mathrm{CH}_{3}$ of 1$), 2.80-2.90(\mathrm{~m}, 2 \mathrm{H}, \mathrm{H \beta}$ of $\mathrm{His})$, 3.05-3.14 (m, $2 \mathrm{H}, \mathrm{H} \beta$ of $\mathrm{Cys}), 3.18-3.49$ (m, 3H, $\mathrm{H} \beta$ of Asn, $\mathrm{CH}_{2}$ of 1), 3.67 (d, $1 \mathrm{H}, J=17.0 \mathrm{~Hz}, \mathrm{H} \alpha$ of Gly), 3.83 (d, $1 \mathrm{H}, J=17.0$ $\mathrm{Hz}, \mathrm{H} \alpha$ of Gly), 4.01 (d, $1 \mathrm{H}, J=12.7 \mathrm{~Hz}, \mathrm{CH}_{2}$ of 1), 4.20-4.59 (m, $7 \mathrm{H}, \mathrm{H} \alpha$ of $\mathrm{Cys}, \mathrm{CH}_{2}$ of Fmoc, $\mathrm{CH}$ of Fmoc, $\mathrm{H} \alpha$ of Fmoc-Ala, $\mathrm{H} \alpha$ of Asn, $\mathrm{H} \alpha$ of His), 6.91 (s, 1H, $\mathrm{H} \delta$ of His), 7.30-7.48 (m, 4H, Arom.), $7.58(\mathrm{~s}, 1 \mathrm{H}, \mathrm{H} \varepsilon$ of His), 7.64-7.76 (m, 2H, Arom.), 7.79-7.90 (m, $2 \mathrm{H}$, Arom.).

Peptide 23 (1-Ala-His-Asn-Ser(Fmoc-Ala-S)-Gly- $\mathrm{NH}_{2}$ ) was obtained (90\% conversion) after treatment of peptide 13 (5 mg, $0.005 \mathrm{mmol})$ with TEA $(1.0 \mu \mathrm{L}, 0.007 \mathrm{mmol})$ in a $24: 1$ mixture of $\mathrm{CD}_{3} \mathrm{CN} / \mathrm{D}_{2} \mathrm{O}$ at room temperature for $3 \mathrm{~h}$. $\mathrm{MS}(\mathrm{ESI}) \mathrm{m} / \mathrm{z}=940.3$, calculated for $\mathrm{C}_{40} \mathrm{H}_{50} \mathrm{~N}_{11} \mathrm{O}_{14} \mathrm{~S}[\mathrm{M}+\mathrm{H}]^{+}=940.3254$. ${ }^{1} \mathrm{H} \mathrm{NMR}(300$ $\mathrm{MHz}, \mathrm{CD}_{3} \mathrm{CN} / \mathrm{D}_{2} \mathrm{O}$ (95:5)) $\delta(\mathrm{ppm}): 1.26-1.38\left(\mathrm{~m}, 6 \mathrm{H}, \mathrm{CH}_{3}\right.$ of Fmoc-Ala, $\mathrm{CH}_{3}$ of Ala), $1.62\left(\mathrm{~s}, 3 \mathrm{H}, \mathrm{CH}_{3}\right.$ of 1$), 2.95-3.06(\mathrm{~m}, 2 \mathrm{H}$, $\mathrm{H} \beta$ of His), 3.28-3.49 (m, $2 \mathrm{H}, \mathrm{H} \beta$ of Asn), 3.64-4.09 (m, $4 \mathrm{H}, \mathrm{CH}_{2}$ of $1, \mathrm{H} \alpha$ of Gly), 4.16-4.68 (m, 9H, $\mathrm{H} \beta$ of Ser, $\mathrm{CH}_{2}$ of Fmoc, $\mathrm{CH}$ of Fmoc, $\mathrm{H} \alpha$ of Fmoc-Ala, $\mathrm{H} \alpha$ of Ala, $\mathrm{H} \alpha$ of Asn, $\mathrm{H} \alpha$ of His), 5.09-5$22(\mathrm{~m}, 1 \mathrm{H}, \mathrm{H} \alpha \mathrm{Ser}), 6.87$ (s, $1 \mathrm{H}, \mathrm{H} \delta$ of His), 7.31-7.49 (m, 4H, Arom.), 7.54 (s, $1 \mathrm{H}, \mathrm{H} \varepsilon$ of His), 7.62-7.72 (m, 2H, Arom.), 7.797.87 (m, 2H, Arom.).

Peptide 24 (1-Ala-His-Asn-Thr(Fmoc-Ala-S)-Gly-NH $\mathrm{NH}_{2}$ was obtained (45\% conversion) after treatment of peptide 14 (5 mg, $0.005 \mathrm{mmol})$ with TEA $(1.0 \mu \mathrm{L}, 0.007 \mathrm{mmol})$ in a $24: 1$ mixture of $\mathrm{CD}_{3} \mathrm{CN} / \mathrm{D}_{2} \mathrm{O}$ at room temperature for $3 \mathrm{~h}$. MS (ESI) $\mathrm{m} / \mathrm{z}=954.3$, calculated for $\mathrm{C}_{41} \mathrm{H}_{52} \mathrm{~N}_{11} \mathrm{O}_{14} \mathrm{~S}[\mathrm{M}+\mathrm{H}]^{+}=954.3410$. ${ }^{1} \mathrm{H} \mathrm{NMR}(300$ $\mathrm{MHz}, \mathrm{CD}_{3} \mathrm{CN} / \mathrm{D}_{2} \mathrm{O}$ (95:5)) $\delta$ (ppm): 1.10-1.20 (m, 3H, $\mathrm{CH}_{3}$ of Thr), 1.27-1.48 (m, $6 \mathrm{H}, \mathrm{CH}_{3}$ of Fmoc-Ala, $\mathrm{CH}_{3}$ of Ala), $1.63\left(\mathrm{~s}, 3 \mathrm{H}, \mathrm{CH}_{3}\right.$ of 1), 2.95-3.21 (m, $4 \mathrm{H}, \mathrm{H} \beta$ of His, $\mathrm{H} \beta$ of Asn), $3.46(\mathrm{~d}, 1 \mathrm{H}, J=$ $12.7 \mathrm{~Hz}, \mathrm{CH}_{2}$ of 1), 3.71 (d, $1 \mathrm{H}, J=17.0 \mathrm{~Hz}, \mathrm{H} \alpha$ of Gly), 3.83 (d, $1 \mathrm{H}, J=17.0 \mathrm{~Hz}, \mathrm{H} \alpha$ of Gly), $4.03\left(\mathrm{~d}, 1 \mathrm{H}, J=12.7 \mathrm{~Hz}, \mathrm{CH}_{2}\right.$ of 1 ), 4.14-4.68 (m, 9H, $\mathrm{H} \beta$ of Thr, $\mathrm{CH}_{2}$ of Fmoc, $\mathrm{CH}$ of Fmoc, $\mathrm{H} \alpha$ of Fmoc-Ala, $\mathrm{H} \alpha$ of Ala, $\mathrm{H} \alpha$ of Asn, $\mathrm{H} \alpha$ of $\mathrm{His}, \mathrm{H} \alpha \mathrm{Ser}$ ), 6.86 (s, $1 \mathrm{H}$, $\mathrm{H} \delta$ of His), 7.31-7.48 (m, 4H, Arom.), 7.54 (s, 1H, Hع of His), 7.637.74 (m, 2H, Arom.), 7.80-7.89 (m, 2H, Arom.).

Peptide 25 (1-Ala-His-Asn-Lys(Fmoc-Ala-S)-Gly-NH $\mathrm{NH}_{2}$ was quantitatively obtained after treatment of peptide $15(5 \mathrm{mg}$,
$0.005 \mathrm{mmol})$ with TEA $(1.0 \mu \mathrm{L}, 0.007 \mathrm{mmol})$ in a $24: 1$ mixture of $\mathrm{CD}_{3} \mathrm{CN} / \mathrm{D}_{2} \mathrm{O}$ at room temperature for $5 \mathrm{~min}$. $\mathrm{MS}(\mathrm{ESI}) \mathrm{m} / \mathrm{z}=$ 981.3, calculated for $\mathrm{C}_{43} \mathrm{H}_{57} \mathrm{~N}_{12} \mathrm{O}_{13} \mathrm{~S}[\mathrm{M}+\mathrm{H}]^{+}=981.3883 .{ }^{1} \mathrm{H} \mathrm{NMR}$ (300 MHz, CD ${ }_{3} \mathrm{CN} / \mathrm{D}_{2} \mathrm{O}$ (95:5)) $\delta$ (ppm): 1.25-1.51 (m, 8H, $\mathrm{CH}_{3}$ of Fmoc-Ala, $\mathrm{CH}_{3}$ of Ala, $\mathrm{H} \gamma$ of Lys), 1.53-1.91 (m, 7H, $\mathrm{CH}_{3}$ of $1, \mathrm{H} \delta$ of Lys, $\mathrm{H} \beta$ of Lys), 2.68-2.80 (m, $2 \mathrm{H}, \mathrm{H} \beta$ of His), 2.86-2.99 (m, $2 \mathrm{H}$, $\mathrm{H} \varepsilon$ of Lys), 3.07-3.28 (m, $2 \mathrm{H}, \mathrm{H} \beta$ of Asn), 3.47 (d, $1 \mathrm{H}, J=12.8 \mathrm{~Hz}$, $\mathrm{CH}_{2}$ of 1$)$, 3.68-3.85 (m, $2 \mathrm{H}, \mathrm{H} \alpha$ of Gly), 4.00-4.70 (m, $9 \mathrm{H}, \mathrm{CH}_{2}$ of 1, $\mathrm{H} \alpha$ of Lys, $\mathrm{CH}_{2}$ of Fmoc, $\mathrm{CH}$ of Fmoc, $\mathrm{H} \alpha$ of Fmoc-Ala, $\mathrm{H} \alpha$ of Ala, $\mathrm{H} \alpha$ of $\mathrm{His}, \mathrm{H} \alpha$ of Asn), 6.86 (s, 1H, $\mathrm{H} \delta$ of His), 7.31-7.47 (m, $4 \mathrm{H}$, Arom), 7.56 (s, $1 \mathrm{H}, \mathrm{H} \varepsilon$ of His), 7.62-7.73 (m, 2H, Arom), 7.80$7.89(\mathrm{~m}, 2 \mathrm{H}, \mathrm{Arom})$.

Peptide 26 (1-Ala-His-Asn-Cys-Gly- $\mathrm{NH}_{2}$ ) was synthesized and purified (method D) following the general protocol described above in a $72 \%$ global yield. Semi-preparative HPLC retention time: $17.28 \mathrm{~min}$. HRMS (ESI) $\mathrm{m} / \mathrm{z}=663.1681$, calculated for $\mathrm{C}_{22} \mathrm{H}_{35} \mathrm{~N}_{10} \mathrm{O}_{10} \mathrm{~S}_{2}[\mathrm{M}+\mathrm{H}]^{+}=663.1974 .{ }^{1} \mathrm{H}$ NMR $(300 \mathrm{MHz}$, $\left.\mathrm{CD}_{3} \mathrm{CN} / \mathrm{D}_{2} \mathrm{O}(95: 5)\right) \delta$ (ppm): 1.35 (d, $3 \mathrm{H}, J=7.2 \mathrm{~Hz}, \mathrm{CH}_{3}$ of Ala), $1.66\left(\mathrm{~s}, 3 \mathrm{H}, \mathrm{CH}_{3}\right.$ of 1$), 2.72-2.81$ (m, $2 \mathrm{H}, \mathrm{H} \beta$ of $\left.\mathrm{His}\right), 2.87-2.98(\mathrm{~m}$, $2 \mathrm{H}, \mathrm{H} \beta$ of $\mathrm{Cys}), 3.03-3.33(\mathrm{~m}, 2 \mathrm{H}, \mathrm{H} \beta$ of Asn), $3.48(\mathrm{~d}, 1 \mathrm{H}, J=12.7$ $\mathrm{Hz}, \mathrm{CH}_{2}$ of 1), 3.69-3.91 (m, 2H, Ha of Gly), $3.99(\mathrm{~d}, 1 \mathrm{H}, J=12.7$

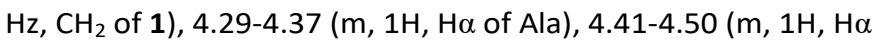
of Cys), 4.58-4.72 (m, 2H, H of His, $\mathrm{H} \alpha$ of Asn), 7.28 (s, $1 \mathrm{H}, \mathrm{H} \delta$ of $\mathrm{His}), 8.51$ (s, $1 \mathrm{H}, \mathrm{H} \varepsilon$ of $\mathrm{His}) .{ }^{13} \mathrm{C} \mathrm{NMR}\left(75 \mathrm{MHz}, \mathrm{CD}_{3} \mathrm{CN} / \mathrm{D}_{2} \mathrm{O}\right.$ (95:5)) $\delta$ (ppm): $16.6\left(\mathrm{CH}_{3}\right.$ of Ala), $22.4\left(\mathrm{CH}_{3}\right.$ of 1$), 25.3$ ( $\mathrm{C} \beta$ of Cys), 26.4 ( $C \beta$ of $A s n$ ), 36.0 ( $C \beta$ of His), 42.1 ( $C \alpha$ of Gly), 49.9 ( $C \alpha$ of Ala), 50.7 ( $\mathrm{C} \alpha$ of His), $51.8\left(\mathrm{CH}_{2}\right.$ of 1 ), 52.4 ( $\mathrm{C} \alpha$ of Asn), 56.0 (C $\alpha$ of Cys), 90.2 (C $\alpha$ of 1), 128.9, 133.6 (Arom), 170.5, 170.6, 171.7, 172.2, 173.1 (CO).

pH-Controlled release analysis. Peptide $\mathbf{1 0}$ was dissolved in PBS ( $50 \mathrm{mM}, \mathrm{pH} 7.4$ or 6.3 , final peptide concentration $100 \mu \mathrm{M}$ ) and incubated at $25{ }^{\circ} \mathrm{C}$. Aliquots were taken periodically and analysed by RP-HPLC using a Waters 1525 HPLC system equipped with a diode array detector $(210 / 254 \mathrm{~nm})$ using the analytical column Phenomenex Luna ${ }^{\circledR} \mathrm{C} 18$ (2) column $(5 \mu \mathrm{m}, 250$ $\mathrm{mm} \times 4.6 \mathrm{~mm}$ ) with a flow rate of $1.0 \mathrm{~mL} / \mathrm{min}$ (linear gradient 595\% B over $30 \mathrm{~min}$ ). Retention times: 21.1 (peptide 10) and 18.8 (peptide 2) $\mathrm{min}$. Chlorambucil was decomposed into various unidentified by-products.

\section{Conflicts of interest}

There are no conflicts to declare.

\section{Acknowledgements}

This work has been supported by grants from the Spanish Ministry of Science and Innovation (MCl) co-financed with FEDER funds (RTI2018-099592-B-C22 and RYC-2013-14706 to GJO; RTI2018-099592-B-C21 to JHB), and the Mizutani Foundation for Glycoscience (200077 to GJO). NM acknowledges Universidad de la Rioja for a predoctoral grant.

\section{Notes and references}


\# The details on optimizing this key synthetic step, which is far from trivial, will be reported elsewhere.

1 Q. Wan and S. J. Danishefsky, Angew. Chem. Int. Ed., 2007, 46, 9248-9252.

2 J. M. Antos and M. B. Francis, Curr. Opin. Chem. Biol., 2006, 10 253-262.

3 I. Romero-Estudillo, C. Saavedra, A. Boto and E. Álvarez, Biopolymers, 2015, 104, 650-662.

4 J. M. Chalker, G. J. L. Bernardes and B. G. Davis, Acc. Chem. Res. 2011, 44, 730-741.

5 C. Poloni, W. Szymański, L. Hou, W. R. Browne and B. L. Feringa, Chem. Eur. J., 2014, 20, 946-951.

6 J. D. Way, C. Bergman and F. Wuest, Chem. Commun., 2015, 51, 3838-3841.

7 F. B. Dyer, C. M. Park, R. Joseph and P. Garner, J. Am. Chem. Soc., 2011, 133, 20033-20035.

8 I. Romero-Estudillo and A. Boto, J. Org. Chem., 2015, 80, 93799391.

9 T. J. Osberger, D. C. Rogness, J. T. Kohrt, A. F. Stepan and M. C. White, Nature, 2016, 537, 214-219.

10 C. J. Saavedra, D. Hernández and A. Boto, Chem. Eur. J., 2018, 24 599-607.

11 R. B. Merrifield, J. Am. Chem. Soc., 1963, 85, 2149-2154.

12 R. B. Merrifield, Angew. Chem. Int. Ed., 1985, 24, 799-810.

13 P. Blaney, R. Grigg and V. Sridharan, Chem. Rev., 2002, 102, 2607-2624.

14 F. Albericio, Curr. Opin. Chem. Biol., 2004, 8, 211-221.

15 V. R. Pattabiraman and J. W. Bode, Nature, 2011, 480, 471-479.

16 J. M. Palomo, RSC Adv., 2014, 4, 32658-32672.

17 V. Castro, H. Rodríguez and F. Albericio, ACS Comb. Sci., 2016, 18, 1-14.

18 Y. Zhu and W. A. van der Donk, Org. Lett., 1998, 37, 1189-1192.

19 E. Calce and S. De Luca, Chem. Eur. J., 2017, 23, 224-233.

20 D. P. Galonić, W. A. Van Der Donk and D. Y. Gin, J. Am. Chem. Soc., 2004, 126, 12712-12713.

21 D. P. Galonić, N. D. Ide, W. A. Van Der Donk and D. Y. Gin, J. Am. Chem. Soc., 2005, 127, 7359-7369.

22 R. E. Meléndez and W. D. Lubell, Tetrahedron, 2003, 59, 25812616.

23 J. F. Bower, J. Švenda, A. J. Williams, J. P. H. Charmant, R. M. Lawrence, P. Szeto and T. Gallagher, Org. Lett., 2004, 6, 47274730.

24 S. B. Cohen and R. L. Halcomb, J. Am. Chem. Soc., 2002, 124, 2534-2543.

25 A. G. Jamieson, N. Boutard, K. Beauregard, M. S. Bodas, H. Ong, C. Quiniou, S. Chemtob and W. D. Lubell, J. Am. Chem. Soc., 2009, 131, 7917-7927.

26 N. Boutard, A. G. Jamieson, H. Ong and W. D. Lubell, Chem. Biol. Drug Des., 2010, 75, 40-50.

27 N. Boutard, S. Turcotte, K. Beauregard, C. Quiniou, S. Chemtob and W. D. Lubell, J. Pept. Sci., 2011, 17, 288-296.

28 I. García-González, L. Mata, F. Corzana, G. Jiménez-Osés, A. Avenoza, J. H. Busto and J. M. Peregrina, Chem. Eur. J., 2015, 21 1156-1168.

29 N. Mazo, I. García-González, C. D. Navo, F. Corzana, G. JiménezOsés, A. Avenoza, J. H. Busto and J. M. Peregrina, Org. Lett., 2015 17, 5804-5807.

30 H. Takeuchi, K. Kato, K. Denda-Nagai, F. G. Hanisch, H. Clausen and T. Irimura, J. Immunol. Methods, 2002, 270, 199-209.

31 U. Karsten, N. Serttas, H. Paulsen, A. Danielczyk and S. Goletz, Glycobiology, 2004, 14, 681-692.
32 N. Gaidzik, U. Westerlind and H. Kunz, Chem. Soc. Rev., 2013, 42, 4421.

33 M. A. Wolfert and G.-J. Boons, Nat. Chem. Biol., 2013, 9, 776784.

34 R. M. Wilson and S. J. Danishefsky, J. Am. Chem. Soc., 2013, 135 14462-14472.

35 N. Martínez-Sáez, J. M. Peregrina and F. Corzana, Chem. Soc. Rev., 2017, 7154, 7154-7175.

36 C. D. Navo, N. Mazo, A. Avenoza, J. H. Busto, J. M. Peregrina and G. Jiménez-Osés, J. Org. Chem., 2017, 82, 13250-13255.

37 H. Staudinger and J. Meyer, Helv. Chim. Acta, 1919, 2, 635-646.

38 E. Saxon and C. R. Bertozzi, Science, 2000, 287, 2007-2010.

39 N. J. Agard, J. A. Prescher and C. R. Bertozzi, J. Am. Chem. Soc., 2004, 126, 15046-15047.

40 S. Bräse, C. Gil, K. Knepper and V. Zimmermann, Angew. Chem. Int. Ed., 2005, 44, 5188-5240.

41 L. Mata, A. Avenoza, J. H. Busto and J. M. Peregrina, Chem. Eur. J., 2013, 19, 6831-6839.

42 A. Avenoza, J. H. Busto, F. Corzana, G. Jiménez-Osés and J. M. Peregrina, Chem. Commun., 2004, 980-981.

43 T. Jiang, E. S. Olson, Q. T. Nguyen, M. Roy, P. A. Jennings and R. Y. Tsien, Proc. Natl. Acad. Sci. U. S. A., 2004, 101, 17867-17872.

44 D. Listunov, S. Mazères, Y. Volovenko, E. Joly, Y. Génisson, V. Maraval and R. Chauvin, Bioorg. Med. Chem. Lett., 2015, 25, 4652-4656.

45 A. F. L. Schneider and C. P. R. Hackenberger, Curr. Opin. Biotechnol., 2017, 48, 61-68.

46 G. Hans-Joachim, The Sugar Code Fundamentals of Glycosciences, Wiley-Blackwell, Weinheim, 2009.

47 T. J. Oman, J. M. Boettcher, H. Wang, X. N. Okalibe and W. A. van der Donk, Nat. Chem. Biol., 2011, 7, 78-80.

48 G. Jiménez-Osés, A. Avenoza, J. H. Busto, F. Rodríguez and J. M. Peregrina, Chem. Eur. J., 2009, 15, 9810-9823.

49 Y. Shin, K. A. Winans, B. J. Backes, S. B. H. Kent, J. A. Ellman and C. R. Bertozzi, J. Am. Chem. Soc., 1999, 121, 11684-11689.

50 F. Thomas, J. Pept. Sci., 2013, 19, 141-147.

51 P. J. H. Scott and P. G. Steel, Eur. J. Org. Chem., 2006, 2251-2268.

52 B. Testa, Curr. Opin. Chem. Biol., 2009, 13, 338-344.

53 R. Mahato, W. Tai and K. Cheng, Adv. Drug Deliv. Rev., 2011, 63, 659-670.

54 E. P. Diamandis and T. K. Christopoulos, Clin. Chem., 1991, 37, 625-636.

55 F. Rusmini, Z. Zhong and J. Feijen, Biomacromolecules, 2007, 8, 1775-1789.

56 G. Dighiero, K. Maloum, B. Desablens, B. Cazin, M. Navarro, R. Leblay, M. Leporrier, J. Jaubert, G. Lepeu, B. Dreyfus, J.-L. Binet, P. Travade, F.-L. Turpin, G. Tertian and A. Bichoffe, N. Engl. J. Med., 1998, 338, 1506-1514.

57 B. Miksa, M. Sierant, E. Skorupska, A. Michalski, S. Kazmierski, U. Steinke, A. Rozanski and P. Uznanski, Colloids Surfaces $B$ Biointerfaces, 2017, 159, 820-828.

58 O. Warburg, The metabolism of tumours, Constable, London, 1930.

59 J. R. Griffiths, Br. J. Cancer, 1991, 64, 425-427.

60 B. A. Webb, M. Chimenti, M. P. Jacobson and D. L. Barber, Nat. Rev. Cancer, 2011, 11, 671-677.

61 E. Persi, M. Duran-Frigola, M. Damaghi, W. R. Roush, P. Aloy, J. L. Cleveland, R. J. Gillies and E. Ruppin, Nat. Commun., 2018, 9, 2997.

62 J. P. Gogarten, A. G. Senejani, O. Zhaxybayeva, L. Olendzenski and E. Hilario, Annu. Rev. Microbiol., 2002, 56, 263-287.

63 Y. Anraku, R. Mizutani and Y. Satow, IUBMB Life, 2005, 57, 563- 
Journal Name

574.

64 J. P. Gogarten and E. Hilario, BMC Evol. Biol., 2006, 6, 94.

65 G. Volkmann and H. D. Mootz, Cell. Mol. Life Sci., 2013, 70, 11851206.

66 F. B. Perler, Cell, 1998, 92, 1-4.

67 G. Jiménez-Osés, A. Avenoza, J. H. Busto and J. M. Peregrina, Tetrahedron Asymmetry, 2008, 19, 443-449. 